\begin{abstract}
BIOSYSTEMATICS OF THE PHACELIA RANUNCULACEA COMPLEX (HYDROPHYLLACEAE)
\end{abstract}

by Matthew Sewell

Phacelia ranunculacea sensu lato (subgenus Cosmanthus, Hydrophyllaceae) occurs on floodplains and in alluvial hardwood forests throughout eastern North America. It is comprised of herbaceous annuals with alternate, pinnate leaves and white to lavender, tubular-campanulate flowers in terminal scorpioid-like cymes. The distribution of populations displays a disjunct between the Midwest and Atlantic coastal plain, with a chromosome number of $n=6$ associated with the former and $n=14$ allied with the latter. A phenetic analysis of morphological characters was conducted using 350 herbarium specimens examined from 18 herbaria. The resulting phenogram revealed two distinct clusters of specimens on which haploid chromosome number was mapped. Correlation of the clusters and chromosome counts with type specimens resulted in recognition of two taxa: Phacelia ranunculacea sensu stricto and Phacelia covillei. Results of morphological analyses, a diagnostic key, species descriptions, and lists of representative specimens are provided for these two closely related species. 


\title{
BIOSYSTEMATICS OF THE PHACELIA RANUNCULACEA \\ COMPLEX (HYDROPHYLLACEAE)
}

\author{
A Thesis \\ Submitted to the \\ Faculty of Miami University \\ in partial fulfillment of \\ the requirements for the degree of \\ Master of Science \\ Department of Botany \\ by \\ Matthew Sewell \\ Miami University \\ Oxford, Ohio \\ 2003
}

Advisor

Dr. Michael A. Vincent

Dr. R. James Hickey

Dr. John Z. Kiss 


\section{TABLE OF CONTENTS}

Page

List of Tables .................................................................... iii

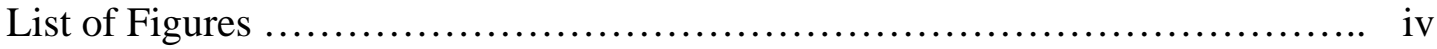

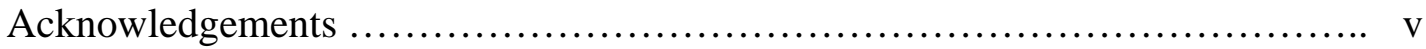

Introduction ................................................................ 1

Materials and Methods …................................................... 6

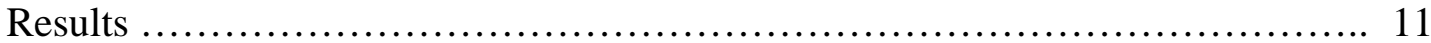

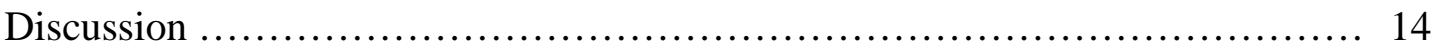

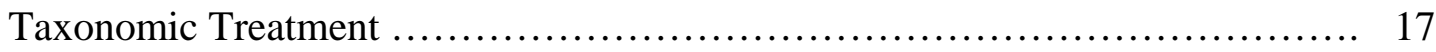

P. covillei .......................................................... 18

P. ranunculacea ........................................................... 21

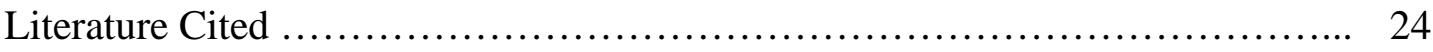

Appendix A- Character histograms ......................................... 44

Appendix B- Specimens examined ....................................... 48 


\section{LIST OF TABLES}

Table

Page

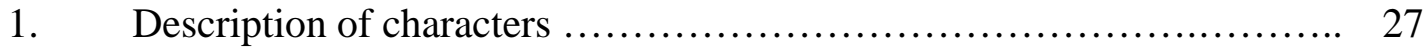

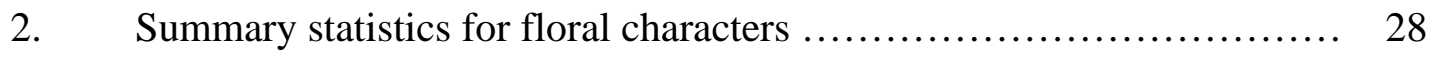

3. Summary statistics for vegetative characters ...................... 29

4. Floral and vegetative character eigenvector values $\ldots \ldots \ldots \ldots \ldots \ldots \ldots \ldots . \quad 30$

5. Results of t-tests ............................................. 31 


\section{LIST OF FIGURES}

Figure $\quad$ Page

1. Distribution of Phacelia ranunculacea s.l. .............................. 32

2. Diagram of leaf measurements ................................ 33

3. Diagram of floral measurements ............................... 33

4a. Scatter plot of basal angle versus corolla lobe width ................... 34

4b. Scatter plot of basal angle versus corolla lobe ratio .................... 34

5a. Scatter plot of basal angle versus terminal leaflet length ................ 35

5b. Scatter plot of basal angle versus terminal leaflet ratio .................. 35

6. Ordination plot of OTUs derived from floral and vegetative data .......... 36

7. Ordination plot of OTUs computed from vegetative data ................ 37

8. Phenogram of OTUs calculated from floral and vegetative data ........... 38

9. Phenogram of OTUs compiled from vegetative data ..................... 39

10. Chromosome count from Pike County, Indiana ...................... 40

11. Chromosome count from Wayne County, Missouri ..................... 41

12. Chromosome count from Lawrence County, Ohio .................... 42

13. Distribution of P. ranunculacea and P. covillei ......................... 43 


\section{ACKNOWLEDGEMENTS:}

First, I would like to thank my advisor Dr. Michael Vincent. His patience and guidance throughout the past few years has been extraordinary. I am not sure I would have completed this endeavor without his assistance. The other members of my committee, Dr. R. J. Hickey and Dr. J. Kiss also deserve a large amount of the credit in helping me through this process. To my fellow graduate students, your camaraderie and moral support were greatly appreciated. Most importantly, I would like to thank my parents, for their support and sacrifices were paramount in my academic pursuits. 


\section{INTRODUCTION:}

The genus Phacelia is the largest and most diverse member of the family Hydrophyllaceae. Jussieu (1789) first described Phacelia and included it with Hydrophyllum and Ellisia in the "Ordo Boraginae" (=family Boraginaceae sensu lato). Brown (1810) moved the genera into the new order "Hydrophylleae", segregating it from the "Boraginae" due to lobed leaves, capsular fruits and cartilaginous endosperm. Asa Gray (1875) produced a single large family by merging what then had become Hydrophyllaceae (Lindley, 1836) with genera previously assigned to the Hydroleaceae. Baillon (1890) placed the Hydrophyllaceae within the Boraginaceae until Brand (1913) again elevated it in rank in the most recent treatment of the entire family. Contrasting classifications by Thorne (1976) and Cronquist (1981), the former aligning the Hydrophyllaceae with the Boraginaceae and the latter placing it closer to the Polemoniaceae, illustrate the difficulties in understanding its familial relationships. Despite the differing taxonomic ranks and relationships assigned to members of the Hydrophyllaceae it is generally accepted that they are characterized by sympetalous, pentamerous flowers arranged in helicoid cymes, and are separated from the Polemoniaceae and Boraginaceae by pistil and fruit characters (Cronquist, 1981). Preliminary cladistic analyses of DNA sequence data suggest that the Hydrophyllaceae is not monophyletic when the circumscription includes the genera Hydrolea and Codon (Ferguson, 1999).

Phacelia is a large and polymorphic assemblage of 150-200 herbaceous annuals and perennials native to the New World (Constance \& Chuang, 1982). The genus is best represented in the western United States and northern Mexico, with a few species extending into South America, and others east of the Mississippi River in North America. It is no surprise, given its size and diversity, that Phacelia also has the greatest range in chromosome numbers within the Hydrophyllaceae, with haploid counts ranging from $n=5$ to $n=24$. The most common haploid number is $n=11$, found in three times as many taxa as the next most prevalent counts, $n=9$ and $n=12$ (Constance, 1963). In spite of the diversity exhibited by the genus, Phacelia constitutes a cohesive group with a circumscription that has had few major changes in the last 150 years. According to $n d h F$ sequence data, there is strong support for the monophyly of Phacelia (Ferguson, 1999). 
Indeed the genetic evidence seems to correlate well with several morphological characteristics of the ovules, seeds, and corolline appendages (intrastaminal scales or glands), features that have historically been used to outline Phacelia. Genera such as Eutoca, Microgenetes, Cosmanthus, and Euphacelia were submerged under Phacelia by Gray (1875), and have served as a basis for more recent subgeneric classifications. These subgeneric classifications were based largely on ovule characteristics and are contradicted by chromosome counts. The classification outlined by Gray (1875), and later adopted by Bentham and Hooker (1876), in addition to those of Brand (1913) and Cronquist et. al. (1984) were based largely on the number and orientation of the ovules and seeds. Constance (1963) argued for a framework based on chromosome number, proposing three subgenera: Cosmanthus, Howellanthus, and Phacelia, based on haploid numbers $n=9,8$, and 11 respectively, with aneuploid and polyploid series found in Cosmanthus and Phacelia ranging from $n=5$ to $n=24$. He added:

All the groupings mentioned show considerable internal consistency in vegetative and floral morphology, geographical and ecological distribution, and in cytology, but cut across the traditional arbitrary divisions based on number of ovules. A reduction in ovule number, in fact, appears to have occurred independently in several of the groups.

Phacelia ranunculacea (Nutt.) Constance was included in the subgenus Cosmanthus in the most recent revision of the group (Constance, 1949). The subgeneric arrangement established by Constance essentially followed Brand's (1913) section Cosmanthus, except for the inclusion of a biennial, $P$. bipinnatifida, in this group of annuals and perennials. Subgenus Cosmanthus is an aggregate of 18 species, with an additional 7 infraspecific taxa, and is separated from other subgenera in Phacelia based on distributional, morphological, and cytological characteristics (Constance, 1949; Turner, 1991).

The collective distributions of species within Phacelia subgenus Cosmanthus suggest a northeastern migration from Mexico and Guatemala (five species) to Texas and Oklahoma (three species), to the Ozarks (three species), finally to the Appalachians (six species more or less east and west of the mountains) (Constance, 1949). One character 
unique to Phacelia subgenus Cosmanthus is the number and distribution of ovules amongst the taxa. A third of the species have 6-14 ovules, another third have 4 ovules and the remaining third have 2 ovules. The distribution of ovules across subgenus Cosmanthus correlates with the geographic distribution of the taxa, in which the higher ovulate species occur in the southwest and those with fewer ovules are found in the northeast. Therefore there appears to be a trend toward a reduction of ovules to a pair per placenta, in contrast to the consistent number of 4 per placenta observed in other subgenera of Phacelia (Constance, 1949). Another character separating the members of subgenus Cosmanthus from the rest of Phacelia is a lack of the corolla scales found bracketing the base of each stamen and adnate to the corolla tube. Subgenus Cosmanthus has an altogether different organ that has been confused with corolla scales. The structure consists of a gland (nectary) or its vestigial remnants found between the stamens, extending distally from the base of the corolla tube to the middle of each corolla lobe and bordered lengthwise by two parallel flaps (Constance, 1949). Cytological investigations of subgenus Cosmanthus reveal the absence of a chromosome number of $n=11$, the most common complement found in the remainder of Phacelia (Constance, 1949). Of the eleven species with published chromosome data (Cave \& Constance 1947, 1950; Constance 1949, 1950, 1963; Gillett 1964, 1968; Murdy 1966) seven species have a haploid number of nine ( $n=9$ ), with $n=5,8$, and 14 also present in the subgenus. Constance (1963) hypothesized $n=9$ was the ancestral complement for the subgenus because it agreed with his notion that less "highly evolved" perennials provided the "evolutionary stock" for each of the three subgenera.

Just as subgenus Cosmanthus is unique amongst Phacelia, anomalies in chromosome number, morphology, and distribution have led Gillett (1968) to place $P$. ranunculacea in a class (Group I) by itself and even predicted that it "ultimately will be recognized as a monotypic genus”. Characters such as a particularly small, tubularcampanulate corolla, spherical to near-spherical seeds (i.e. "keelless"), and filaments without hairs distinguish $P$. ranunculacea from the rest of subgenus Cosmanthus. Although the corolla glands are apparently functional as nectaries only in P. bipinnatifida (Constance, 1949), the adjacent parallel flaps are present in all species of the subgenus. However, in P. ranunculacea the parallel flaps (i.e. “nectar flaps”) are often barely 
visible, the position of the aborted gland only faintly indicated by two minute ridges at the very base of the corolla tube (Constance, 1949).

Phacelia ranunculacea is found on moist river alluvia in well-shaded habitats of bottomland hardwood forest (Gillett, 1968). Many of these sites undergo seasonal flooding, an adaptation to which is most unusual for a taxon in Phacelia. Nuttall (1837) first described Phacelia ranunculacea as Ellisia ranunculacea Nutt. from the "shady humid alluvial forests of the Arkansas". Nuttall's collection is mixed, containing both Ellisia ranunculacea Nutt. and Ellisia microcalyx Nutt., which led Gray (1875) to consider the names synonymous. As a result the name Nemophila microcalyx (Nutt.) Fisch. \& Mey. was misapplied to what he thought was one species. Watson (in Gray et. al., 1890) described a strikingly similar species named Phacelia covillei S. Wats., found on an island in the Potomac River near Washington, D.C. The synonymy of P. covillei and E. ranunculacea was later postulated by Constance (1940).

The geographic distribution of $P$. ranunculacea is not only unique amongst subgenus Cosmanthus but also compared to almost all other eastern North American taxa by exhibiting populations disjunct in the Midwest and the Atlantic coastal plain (Harvill, 1969) (Figure 1). Populations are scattered, with an apparent separation between Maryland, Virginia, Washington, D.C., and North Carolina east of the Appalachians, and Ohio, West Virginia, Indiana, Illinois, Kentucky, Tennessee, Missouri, Arkansas, and Mississippi west of the Appalachians. Phacelia ranunculacea is not federally listed as rare or endangered, but it has been accorded conservation status that varies according to each individual state. The species is "endangered” in Maryland (M.N.H.P., 1988), Indiana (Bacone and Hedge, 1979) and Ohio (O.D.N.R., 2002), "primary proposed” in North Carolina (Sutter et. al., 1983), and recognized in Kentucky (K.S.N.P.C., 2000) and Tennessee (Somers, 1989) as a species of "special concern".

The chromosome first count for P. ranunculacea s.l. $(n=14)$ was obtained from material along the Potomac River near Washington, D.C. (Constance, 1949), and later confirmed by a count from a population in central North Carolina (Chuang \& Constance, 1977). Despite the attractive possibilities of synthesizing $P$. ranunculacea from others within Cosmanthus, for example P. maculata or P. dubia $(n=5)$ with one of the $n=9$ species, it is difficult to explain the morphological characteristics that make $P$. 
ranunculacea such a distinctive plant. Further complicating the matter is material collected in the 1960's and 1970's from Kentucky, Illinois, Tennessee and Missouri, in which the counts showed a haploid chromosome number of six $(n=6)$ (Chuang \& Constance, 1977). For the last quarter century P. ranunculacea has been considered a widespread taxon with "eastern” $(n=14)$ and "western” $(n=6)$ cytotypes.

The purpose of this study is to reexamine the identities of the "eastern" and “western” populations of Phacelia ranunculacea s.l., with particular attention paid to populations not sampled by Chuang and Constance (1977) such as those in Ohio, West Virginia, and Indiana. The concept of a single, widespread, cytologically and morphologically diverse taxon is put forward as the null hypothesis. An alternative hypothesis proffered is that what has been historically been called Phacelia ranunculacea (Nutt.) Constance represents at least two reproductively and geographically isolated entities. The primary goal of this study is to discern whether any morphological characters consistently correlate with the different chromosome numbers in these disjunct groups of populations. If any correlation can be found between morphological features and chromosome numbers then a clear definition of natural biotic units can be described, and the appropriate nomenclature applied. To this end, aspects of floral and vegetative morphology were measured and analyzed phenetically via several statistical techniques. Additional chromosome counts were obtained from populations without cytological data. 


\section{MATERIALS AND METHODS:}

This study compared both the macro and micro-morphological features of specimens attributed to Phacelia ranunculacea (Nutt.) Constance sensu lato. Herbarium sheets were examined from the following herbaria: BRIT/SMU/VDB, EKY, F, GMUF, ILL, IND, KNK, KY, NCU, NY, MO, MU, TENN, UC/JEPS, US, VPI, WKU, and WVA. Out of approximately 350 specimens, 331 were of significant quality that they contained enough measurable vegetative features for analysis. A subset of 55 of the original 331 sheets with adequate floral material was scored for 17 characters. Most specimens contained more than one plant and consequently each individual served as a separate operational taxonomic unit (OTU). Every OTU was assigned a two-letter and four-digit abbreviation as a label to identify it during data analysis (see Appendix B). The letters indicate the state and the first two numbers denote the population from which the specimen was collected. Duplicate specimens, as well as collections made by others at different times, were given the same population number if locations could be precisely correlated using herbarium label data and verified in the field. Assignment of population codes was conservative and any doubt resulted in the application of different numbers. The last two numbers refer to an individual plant. Often measurements were taken from more than one plant on a sheet, resulting in multiple OTU codes for the same specimen. This was especially true for many chromosome vouchers and sheets with flowering material.

Thirty-seven morphological characters were scored for each OTU (Table 1; Figures 2 \& 3). The data were grouped into floral, vegetative sets, and a combined dataset. Twenty-two quantitative characters (13 floral and 9 vegetative) were coded as continuous data. Fifteen qualitative characters (11 vegetative and 4 floral) were coded as discrete values, whether the values were binary or multistate positive integers. All sheets used in the morphological analysis were fertile, and sheets used to measure floral characters had six or more "dissectable" flowers. Care was taken to dissect flowers that were approximately the same age in terms of phenology. The character states were recorded as follows (character number in parentheses):

Terminal leaf (uppermost leaf on a stem, directly subtending an inflorescence): Terminal leaflet length (1) and width (2) at the widest point were recorded (Figure 2). Terminal 
leaflet width/length ratio (3) was calculated to describe the overall shape of the leaf and to minimize any differences in individual length and width measurements related to leaf maturity and/or the micro-environment effects (i.e. larger leaves in shade). Laminar basal angle (4), to the nearest degree, was recorded (Figure 2). The total number of leaflets was recorded (5). The number of lobes per apical (6) and basal (7) lateral leaflet was recorded (Figure 2). Petiole length (8) was measured, as well as overall indument (9) (0=glabrous; $1=$ =pubescent), and presence or absence of glandular trichomes (10). Petiole width was measured but not entered in the data set due to the varying degrees to which it was folded over on itself, an artifact of pressing. The number of secondary sinuses of the terminal leaflet (11) was tallied. Secondary sinuses were defined as those other than the two primary sinuses formed by the three main lobes of the terminal leaflet. The position and number of veins of the terminal leaflet were examined but not entered in the data set because of an inability to objectify the measurements. This was due to differing levels of maturity of each specimen (veins were obscured in smaller/younger leaves) and micro-environmental factors in habitat that affect leaf size and thickness (veins were more easily distinguished in larger/thinner leaves).

Stem: The stem indument was characterized by describing the differing aspects of the trichomes found along the middle portion of the stem. The section of the stem above the basal rosette of leaves and below but not immediately subtending an inflorescence, corresponding to an area between the second and sixth nodes from the base of the plant, was evaluated as to the type and arrangement of simple, unicellular hairs (12) and glandular trichomes (13). Primarily strigose, with only a few spreading or retorse hairs, was coded as zero. Conversely, straight hairs mostly spreading or pilose, rarely appressed or ascending, was entered as one. Moniliform shaped trichomes with stipitate/capitate glands [a combination of terms from Figure 3.12 in Walters and Keil (1975) and Figure 7.7 in Radford et. al. (1974)] were coded as zero for sparse and short (all $<2 \mathrm{~mm}$ ) or one for dense and long (most $>2 \mathrm{~mm}$ ).

Leaf surface: The surface vestiture of an upper leaf on the stem was examined. The particular leaf chosen was neither terminal on the stem nor directly subtending an inflorescence. The adaxial (14) and abaxial (15) sides were coded as either glabrous or 
pubescent to describe the overall indument. The presence or absence of glandular trichomes on both the adaxial (16) and abaxial (17) surfaces of the leaf was also noted. Inflorescence: The primary peduncle (18) of the scorpioid cyme was scored as glabrous or pubescent. More specifically the type of pubescence was noted by the presence or absence of glandular trichomes (19). The pedicel indument (20) of the terminal flower on the inflorescence was coded as glabrous or pubescent. Glandular trichomes on the pedicel (21) were scored as present or absent.

For floral measurements, each flower was removed and soaked in 1\% Aerosol OT for several minutes to soften the tissue for dissection. The corolla tube was split along one side with a razor blade and removed from the calyx and pistil as one piece. The corolla tube was spread flat on a microscope slide with the inner portion of the corolla tube facing up in order to view the epipetalous stamens. All the floral measurements were made with an ocular micrometer on a Wild model M3 dissecting microscope.

Calyx: The length (22) and width (23) of one sepal was measured (Figure 3). The indument of the sepal (24) and the presence or absence of glandular trichomes (25) was noted. The overall length (26) and the length of the division of the bifid style (27), or style cleft length, were recorded (Figure 3). To quantify the degree to which the style was divided, a ratio of style length to style cleft length (28) was calculated. The indument of the ovary (29) was noted as glabrous or pubescent.

Corolla: Corolla length (30) was measured from the base of the corolla tube to the tip of one of the corolla lobes (Figure 3). Corolla lobe width (31) and corolla lobe length (32) were also recorded. A ratio of the corolla lobe width and corolla lobe length (33) was calculated to describe the overall proportions of the corolla lobe. Filament length (34) was measured from the point of insertion on the corolla tube to the base of the anther. Anther length (35), anther width (36), and filament indument (37) were also recorded. Nectar flap length refers to the parallel flaps of tissue found at the base of the corolla tube (Figure 3).

Data for all variable characters (see Table 1) per OTU were entered into a Microsoft Excel spreadsheet. Initial exploration of the data was accomplished by 
constructing histograms for each character (Appendix A). Characters with distributions that appeared bimodal were used to construct bivariate scatter plots to investigate any character correlation patterns. The Excel spreadsheet was imported into NTSYS-pc 2.1 (Rohlf, 2002) for phenetic analysis. A linear transformation of the measurements was performed to standardize the data thus minimizing the effects of the different scales of measurement for some characters. The similarity interval command SIMINT (correlation coefficient code CORR) was used to build a separate similarity matrix for each dataset. The similarity matrices used in the principle components analyses (PCA) were computed by columns, which corresponded to the characters (variables). Eigenvalues and eigenvectors were calculated and plots of the OTUs against the first two principle components were made. The sequential, agglomerative, hierarchical and nested clustering method (SAHN), using the default unweighted pair group method of arithmetic averages (UPGMA), was used to produce phenograms based on the similarity matrices calculated by OTUs (i.e. rows). Cophenetic values, or coefficients of correlation (r), were computed to test how well the phenogram represented the original similarity matrix. The variation in the data explained by the character-loadings for each eigenvector, as illustrated by the first three principle components, and the distributions shown by the histograms were used as a basis for including or excluding characters in successive clustering analyses. Alternatively, characters that displayed a normal distribution and exhibited a low amount of variability according to the eigenvector character-loadings were not regarded as informative and excluded from subsequent analyses because they did not contribute to the separation of OTUs into clusters. The above procedure was repeated for each of the three sets of data and the phenograms were compared. Pairwise comparisons of all characters were conducted in Microsoft Excel using a t-test (two sample-assuming unequal variances) to check for significant differences between the groups of OTUs outlined by the SAHN clustering module.

Chromosome counts were performed on material from populations in the following counties visited during the spring of 2001-2003: Lawrence (Ohio), Wayne (Missouri), and Pike (Indiana) (see Appendix B for location data for all populations visited by the author). Flower buds and seeds were harvested from the field to provide material for counts. Seeds were grown in the Miami University greenhouse to harvest 
additional flower buds or root tips. Flower buds and root tips were fixed in a saturated solution of paradichlorobenzene (PDB) for approximately 4-6 hours. The material was transferred to Farmer's solution (3:1; ethanol: glacial acetic acid) for long-term storage. Meiotic counts of anther material followed Belling's Iron-acetocarmine protocol (Johansen, 1940). Mitotic counts of root tip material followed a generalized acetocarmine staining procedure (Sass, 1958). Root tips were hydrolyzed in $1 \mathrm{~N} \mathrm{HCl,}$ rinsed in 95\% ethanol, stained with acetocarmine, and destained in glacial acetic acid. Both meiotic and mitotic material was placed on a microscope slide under a cover slip, spread out with a pencil eraser and examined with an oil emersion lens of an Olympus BH-2 light microscope. Specimens collected by the author that correspond to chromosome counts are populational vouchers. Populations with counts, including those performed by others in the past, were mapped onto the phenogram and scatter plots of morphological data for comparison. 


\section{RESULTS:}

Characters that were not only variable but that could also separate OTUs into groups were deemed as informative; the establishment of which was needed to help evaluate any connection between morphology and chromosome number. The first step in determining the most informative characters was the construction of histograms. Histograms revealed that the distribution of the terminal leaflet basal angle was the most distinctly bimodal of all the characters measured. Some degree of bimodality was seen in two other vegetative characters (3.terminal leaflet length and 5.terminal leaflet length/width ratio) and two floral characters (24.corolla lobe width and 33. corolla width/length ratio) (see Appendix A). Scatter plots of terminal leaflet basal angle versus each of the above characters were made to ascertain if any correlations could be found. The resultant plots showed two clusters of OTUs (Figures 4 \& 5). However, out of all the characters, most of the separation was accounted for by the terminal leaflet basal angle. Plots containing characters that represented the proportional shapes of the corolla lobes and terminal leaflets as ratios formed the tightest clusters (Figures 4B \& 5A). Mapping the presence/absence stem pubescence data onto the scatter plots reinforced these clusters. The presence/absence stem pubescence data displayed a direct correlation with the two clusters (Figures 4 \& 5). Appressed hairs and small/sparse glands corresponded strongly with wider than long corolla lobes, longer than wide terminal leaflets and acute terminal leaflet bases. Conversely, spreading hairs with large/dense glands displayed a match with obtuse terminal leaflet bases, as well as terminal leaflets and corolla lobes with dimensions closer to a 1:1 ratio. Simple hairs and glandular trichomes were scored as separate characters; in no case were plants observed that combined appressed hairs and large/dense glands or spreading hairs with small/sparse glands.

Principle components analysis (PCA) was used to investigate variability in the data and illustrate how the variation was partitioned among each character. Exploration of the floral and vegetative dataset revealed $30.75 \%$ of the total variation was accounted for by the first principle component (PC I), with $15.94 \%$ and $10.26 \%$ of the variation represented by the second (PC II) and third (PC III) principle components respectively (Table 5). An ordination plot of OTUs against the first two principle components (Figure 6) reflected the same morphological separation observed in the bivariate scatter plots. 
Cluster analysis of all the floral and vegetative characters produced a phenogram with two groups of OTUs that corresponded to the separation portrayed by the ordination and bivariate scatter plots. The correlation coefficient $(r=0.83)$ calculated from the phenogram based on all the floral and vegetative characters depicted a moderate to good fit of the cluster analysis in terms of representing the original similarity matrix. The next step was to ascertain which, if any, of the characters were more responsible than others in the formation of the two groups of OTUs observed in the floral and vegetative phenogram.

Discerning which were the most informative characters was facilitated by the considerable agreement amongst characters that represented most of the variation and those with bimodal distributions. According to the eigenvector character-loadings, two floral (24.corolla lobe width and 31.sepal length) and three vegetative characters (6.terminal leaflet basal angle, 10.midstem pubescence, and 11.midstem glandular trichomes) contributed most of the variation as expressed by PC I (Table 4). None of the characters appeared to add an appreciable amount of variation to PC II and PC III relative to the first principle component. Although the terminal leaflet length/width ratio and terminal leaflet length exhibited some bimodality, according to PCA neither was appreciably variable. On the other hand, sepal length accounted for a significant amount of variation in PC I (Table 4), yet the character distribution was normal across all OTUs. Corolla lobe width/length ratio, the variable with the sixth highest character-loading according to PCA, had a bimodal distribution and thus was substituted for sepal length in the cluster analysis of the five most informative characters. The resulting phenogram (Figure 8) produced the same separation in OTUs produced by the ordination projection and scatter plots. In addition, the clusters were tighter and correlation coefficient depicted an extremely good fit $(r=0.97)$ compared to the results of clustering on all floral and vegetative characters.

An ordination plot based on a principle component analysis of just the vegetative characters (Figure 7) revealed the same separation in clusters as the plot constructed from the floral and vegetative dataset (Figure 6). The eigenvector character-loadings pointed to the high degree of variation in terminal leaflet basal angle, midstem pubescence and midstem glandular trichomes. These terminal leaflet and stem characters were the same 
three most variable vegetative characters indicated by the PCA of the floral and vegetative dataset, and had character-loading values were almost identical. A phenogram (Figure 9) based on the dissimilarity matrix of these characters duplicated the same separation in clusters as the clustering analysis of the five most informative floral and vegetative characters. Principle components analysis of only floral characters failed to demonstrate any separation in OTUs. Furthermore, clustering analyses on all character permutations produced phenograms that were discordant with those generated by the vegetative and floral/vegetative datasets.

Meiotic chromosome counts from populations in Lawrence County, Ohio and Pike County, Indiana revealed a haploid complement $n=14$. Individuals from Lawrence and Pike counties exhibited a morphology consistent with specimens from North Carolina, Virginia, Maryland, Washington, D.C., Illinois, and Missouri (Figures 8 \& 9). A haploid complement $n=6$ was found from a population in Wayne County, Missouri. Morphological analysis of the Wayne County material reflected a similarity with other populations in Missouri as well as those in Arkansas, Kentucky, Tennessee, Illinois, Mississippi, and Indiana (Figures 8 \&9). Vouchers supporting previously reported chromosome counts were highlighted in each of the phenograms and correlate precisely with the morphological differences.

The bivariate scatter plots, ordination plots, and phenograms demonstrated the same phenotypic differences between the two groups of OTUs. Just as different chromosome numbers were linked to the differing morphologies in the phenograms (Figures $8 \& 9$ ), the same trend was observed when mapped onto the ordination plots of OTUs against the principle components (Figures $6 \& 7$ ). In addition to the clusters in all the figures being commensurate, the individual OTUs were equivalent as well. Thus, the solid bar in the phenograms, the darkened triangles in the ordination plots and the darkened triangles in the scatter plots denote the same OTUs. The reverse is also true concerning OTUs depicted by the striped bar and the open circles. Accordingly, the clusters in the scatter plots can also be defined in terms of chromosome number. The per character averages distributed by group can be found in Tables $2 \& 3$. 


\section{DISCUSSION:}

A clearer picture of the specific characters that differentiate the groups of OTUs was achieved by comparing the results of PCA and clustering analyses between different datasets. The dataset of vegetative characters produced an ordination plot similar to that of the dataset of both floral and vegetative characters (Figures $6 \& 7$ ), whereas a plot using only floral characters had no discernable clusters. Similarly, the phenograms constructed using the vegetative and floral/vegetative data were congruent (Figures 8 \& 9), while the clustering on only floral characters produced a phenogram without any cohesive clusters. Thus, the influence of the vegetative characters, particularly attributes of the stem pubescence and terminal leaflet bases, factored predominantly in the separation of OTUs. In fact, these same characters delimit two other species in subgenus Cosmanthus. Phacelia purshii Buckl. and P. fimbriata Michx. were circumscribed based on the arrangement of hairs along the stem and the angle of the lobes on the cauline leaves (Constance, 1949). That is not to say the floral characters were altogether uninformative in $P$. ranunculacea s.l. On the contrary, nine of the 13 floral characters showed a significant difference between the groups outlined by the scatter plots, ordination projections and phenograms (Table 5). Although differences in the floral characters suggest the existence of two separate, biological entities, the usefulness of such characters in a taxonomic framework is restricted. For example, the average style length between the two cytotypes is statistically different, but the distinction between 1.32 and $1.51 \mathrm{~mm}$ is so small as to be useless in a diagnostic key. The same is true of the vegetative characters where seven of nine are significantly different according to two sample t-tests (Table 5). Although individuals with the "eastern” cytotype had fewer secondary sinuses and more total leaflets per upper cauline leaf compared to the “western” cytotype, distinguishing 1.02 versus 1.59 sinuses and 2.99 versus 2.78 leaflets is impractical. The obvious differences in terminal leaflet basal angle, the lowest p-value among all characters in Table 5, combined with the clear distinction in stem pubescence presence/absence data, demonstrate the usefulness of these three vegetative characters in a diagnostic key. Therefore, appressed hairs with small/sparse glands, acute terminal leaflet bases, and a $n=14$ chromosome number indicate a single entity. Similarly, 
spreading hairs with large/dense glands, obtuse terminal leaflet bases, and a haploid complement $n=6$ suggest a separate taxon.

The null hypothesis of this study was that the specimens represented one widespread species, Phacelia ranunculacea sensu lato. The alternative hypothesis was that the study sample represented two species, $P$. ranunculacea s.s. and $P$. covillei. Based on differences in morphology and chromosome number, the null hypothesis is rejected and the alternative hypothesis is accepted. In conclusion, the validly published epithet Phacelia covillei, a longtime synonym of $P$. ranunculacea, should be recognized as a separate taxon. Diagnostic keys, pertinent type information, species descriptions, phenology, biogeography, representative specimens and notes are provided in the Taxonomic Treatment below.

The placement of the $P$. ranunculacea complex both within Phacelia and the Hydrophyllaceae as a whole has been debated for years (Constance, 1949, 1977; Gillett, 1968). Gillett (1968) relied on chromosome number $(n=14)$ and the unequal insertion of the stamen filaments on the corolla tube as evidence for suggesting a relationship with the genus Nama. The recent discovery of a chromosome number $n=6$ within $P$. ranunculacea sensu lato (Constance, 1977; this study), together with solitary flowers, simple leaves, and many ovules in Nama contradicts this idea. Moreover, only about $10 \%$ of the flowers dissected for this study had unequally inserted filaments on the corolla (Sewell, pers. obs.). Constance $(1940,1977)$ pointed out the superficial similarities that $P$. ranunculacea s.l. shares with Ellisia nyctelea L. and Nemophila aphylla (L.) Brummitt (=N. microcalyx) in terms of habit, habitat, and size and shape of the corolla. However, tribal distinctions within the Hydrophyllaceae, tribe Hydrophyleae (Ellisia, Nemophila) versus tribe Phacelieae (Phacelia), preclude placing $P$. ranunculacea s.l. in the former. Ellisia and Nemophila have corollas contorted in bud, swollen placentae, and a unilocular ovary. The corollas of P. ranunculacea s.l. are imbricate in bud and the two narrow placentae project into the ovary and partition it into two locules (without fusing). In addition, E. nyctelea has fimbriate corolla scales and solitary flowers whereas $N$. aphylla has cucullate seeds and auriculate calyx sinuses (Constance, 1939), all of which are absent in P. ranunculacea s.l. Thus, the nearest affinities are with Phacelia, and features of the corolla scales and ovules, as well as 
chromosome number and distribution suggest a comfortable placement within subgenus Cosmanthus. 


\section{Taxonomic Treatment}

Key to the species of Phacelia ranunculacea s.l.

1a. Pubescence along middle portion of stem (main axis of the plant above the basal leaves but not immediately subtending an inflorescence, more or less corresponding to the region between the $2^{\text {nd }}$ and $5^{\text {th }}$ nodes) sparse, of mostly appressed/strigose hairs, rarely spreading, with a few short $(<2 \mathrm{~mm})$ moniliform stipitate/capitate glandular trichomes; terminal leaflet of leaves directly subtending an inflorescence with acute $\left(<90^{\circ}\right)$ to cuneate or nearly attenuate bases........................................... Phacelia covillei

1b. Pubescence along middle portion of the stem of mostly spreading/pilose hairs, some retrorse, with long (most $>2 \mathrm{~mm}$ ) and dense moniliform stipitate/capitate glandular trichomes; terminal leaflet of leaves directly subtending an inflorescence with obtuse $\left(>90^{\circ}\right)$ to rounded or almost truncate bases............................................ Phacelia ranunculacea 
1. Phacelia covillei S. Watson ex A. Gray, Man. N. Amer. Bot. ed. 6. 360. 1890. TYPE:

United States. Maryland: Montgomery County; 12 May 1889, Coville s.n.

(lectotype, to be designated: GH! (two plants on the upper left of sheet); isotypes: KY!, US!)

Plants annual, (5-) 10-30 cm high at anthesis, simple or branching from near the base, the branches prostrate to erect. Stems strigose at base, the middle portions strigose, glandular with a sparse mixture of short $(<2 \mathrm{~mm})$ moniliform stipitate/capitate trichomes. Cotyledons petiolate, persistent at anthesis, ovate to orbicular, 0.5-5.0 cm long, 0.5-1.5 $\mathrm{cm}$ wide, tinged with purple, strigulose above, glabrous below. Basal leaves petiolate, pinnate, 3.0-8.0 cm long, (0.5-) 1.0-2.5 cm wide; lateral leaflets 2-6, paired, orbicular to oval, lobed or entire; terminal leaflet larger, obovate, trilobed, often with several smaller lobes. Cauline leaves petiolate, pinnate, (1.0-) 3.0-10.0 (-15.0) cm long, (0.5-) 1.5-3.0 cm wide; lateral leaflets 1-6, usually paired, orbicular to lanceolate, entire or with one to several smaller lobes; terminal leaflet larger, trilobed, often with several smaller lobes, lamina strigose on both surfaces; terminal leaflet of uppermost leaves with acute to cuneate or nearly attenuate bases. Inflorescence terminal, cymose, weakly scorpioid, 2.0$5.0 \mathrm{~cm}, 1-6$ flowered, hirsutulous, glandular with moniliform stipitate/capitate trichomes; mature pedicels (5-) 8-15 mm long, spreading-reflexed to pendent. Sepals linearlanceolate (2.5-) 3.5-5.0 mm long, 0.5-1.5 mm wide, subequal, acute, strigose on abaxial and adaxial surfaces, sparsely glandular with moniliform/capitate trichomes near base. Corolla pale violet, tubular campanulate, 3.0-5.0 mm long, 2.0-4.0 mm wide; limbs erect, 0.8-2.0 mm long, 1.0-2.6 mm wide, oblong to obovate, entire, glabrous; gland flaps inconspicuous, $0.25-0.45 \mathrm{~mm}$ long, reduced to two minute ridges at the very base of the tube. Stamens included, 1.0-2.5 mm long, anthers oblong, 0.3-0.65 mm long, 0.3-0.55 $\mathrm{mm}$ wide, intorse, filaments glabrous. Style included in flower, when mature 0.8-2.5 mm long, cleft from 1/3 to 2/3, glabrous; ovary hirsute, ovules 2 per placenta. Capsule depressed-globose, 4.0-6.0 $\mathrm{mm}$ in diameter when mature, markedly distended by the seeds; seeds 2-4, globose-ovoid, 2.0-2.5 mm long, brown, reticulate. Chromosome number: $n=14$ (Chuang \& Constance 1977; Constance, 1949; this study). 
Habitat and Distribution (Figure 13). Phacelia covillei is found on the shaded rich soils of floodplains and the adjacent slopes of alluvial woods. The range includes several disjunct areas, including the upper Potomac River drainage (Washington, D.C., northern Virginia, and south-central Maryland), drainages of the Cape Fear and Tar Rivers (central North Carolina), and parts of the Ohio River drainage (southeastern Ohio and western West Virginia). Weakely (2003) reports this species from the Roanoke River drainage in south central Virginia, though no specimens documenting this have been seen by the author. Another unconfirmed record for $P$. covillei has been reported from western Illinois in Adams county (Gleason, 1903). Excluding the populations in Ohio and West Virginia, the above distribution has been referred to as ‘Appalachian’ (Cronquist, 1988; Gleason \& Cronquist, 1991). Even with the inclusion of the Ohio and West Virginia populations, the term would be appropriate save for the occurrence of several $P$. covillei populations in the mid-west. The drainage of the Wabash River in southern Indiana and southern Illinois has yielded several populations and another has been located in Texas County, Missouri. The identity of the populations in Texas County may be questioned without an accompanying chromosome count, nevertheless the morphology of plants from this population undoubtedly agrees with that of $P$. covillei. The basal angle measurements of the terminal leaflets range from $66^{\circ}$ to $81^{\circ}$ and the stem pubescence precisely matches the morphology specimens with a $n=14$ chromosome count. Phenology. Phacelia covillei flowers in late March to mid April, and occasionally at the beginning of May in the northern part of the range, with fruit set immediately following. The seeds fall soon thereafter, upon desiccation and dehiscence of the capsule. Notes. Several factors point to a need for lectotypification of P. covillei. Watson indicated neither a collection number nor a date in his protologue. Furthermore, the original sheet at the Gray Herbarium contains material of two collections, both made by Coville at the same locality but on different dates, 5 May and 12 May 1889. The word "type" is written in an unknown hand above the label with the 12 May date. Indeed, in his revision of subgenus Cosmanthus, Constance (1949) did specify the 12 May collection as the type for $P$. covillei. However, Constance was not explicit in his lectotypification, presumably since he subsumed $P$. covillei under $P$. ranunculacea. To add to the confusion, the material on the GH sheet appears to have been switched when 
mounted, with what appears to be younger material associated with the label containing the later date. In fact the duplicate deposited at KY is also a mixed collection but with the younger material associated with the label giving the earlier date. Despite the aforementioned uncertainty the two plants above the 12 May label and associated with the word "type" will be designated as the lectotype as this seems the most conservative option and follows the precedent set by Constance.

Although P. covillei is rare, it is often locally abundant, and the author has found several populations for which there were no previous records. That is not to say that the conservation status afforded P. covillei (as P. ranunculacea) is unjustified. On the contrary, the microhabitat shade and moisture requirements seem very specific, resulting in concentrated populations with well-defined boundaries, sometimes occurring on only one side of a river. Phacelia covillei (as P. ranunculacea) had been categorized as “endangered” and “primary proposed” in Maryland (M.N.H.P., 1988) and North Carolina (Sutter et. al., 1983) respectively, but is absent any such designation in Virginia and West Virginia (see notes under $P$. ranunculacea for discussion of populations in Indiana, Illinois and Missouri). 
2. Phacelia ranunculacea (Nutt.) Constance, Rhodora 42: 39. 1940. Ellisia ranunculacea Nutt. Trans. Amer. Philos. Soc. N. S. 5: 191. 1837. TYPE: United States. Arkansas, s.d., Nuttall s.n. (lectotype, to be designated: BM; photo: UC!; isotype: K; photo: UC!, GH!)

Plants annual, (5-) 10-25 cm high at anthesis, simple or branching from near the base, the branches prostrate to erect. Stems strigose at base, the middle portion pilose, glandular with a dense mixture of long ( $>2 \mathrm{~mm}$ ) moniliform stipitate/capitate trichomes. Cotyledons petiolate, persistent at anthesis, ovate to orbicular, 1.0-5.0 cm long, 0.5-1.5 $\mathrm{cm}$ wide, tinged with purple, sparsely strigulose above, glabrous below. Basal leaves petiolate, pinnate, oblong to ovate 3.0-10.0 cm long, (0.5-) 1.0-2.5 cm wide; lateral leaflets 2-6, paired, orbicular to oval, lobed or entire; terminal leaflet larger, obovate, trilobed, often with several smaller lobes. Cauline leaves petiolate, pinnate, (1.0-) 3.0$10.0 \mathrm{~cm}$ long, $1.0-4.5 \mathrm{~cm}$ wide; lateral leaflets 1-6, usually paired, orbicular to lanceolate, entire or with one to several smaller lobes; terminal leaflet larger, trilobed, often with several smaller lobes, lamina strigose on both surfaces; terminal leaflet of uppermost leaves with obtuse to rounded or almost truncate bases. Inflorescence terminal, cymose, weakly scorpioid, 1.5-5.0 cm, 1-6 flowered, hirsutulous, glandular with moniliform stipitate/capitate trichomes; mature pedicels 8-15(-21) mm long, spreading-reflexed to pendent. Sepals linear-lanceolate 2.0-5.0 mm long, 0.5-1.5 mm wide, subequal, acute, strigose on abaxial and adaxial surfaces, sparsely glandular with moniliform stipitate/capitate trichomes near base. Corolla pale violet to white, tubular campanulate, 2.5-5.5 mm long, 2.0-4.0 mm wide; limbs erect, 0.8-2.1 mm long, 0.8-2.0 mm wide, ovate to obovate, entire, glabrous; gland flaps inconspicuous, $0.2-0.4 \mathrm{~mm}$ long, reduced to two minute ridges at the very base of the tube. Stamens included, 1.0-2.5 mm long, anthers oblong, 0.25-0.5 mm long, 0.25-0.45 mm wide, intorse, filaments glabrous. Style included in flower, when mature 1.0-2.0 mm long, cleft from $1 / 3$ to $2 / 3$, glabrous; ovary hirsute, ovules 2 per placenta. Capsule depressed-globose, 4.0-6.5 $\mathrm{mm}$ in diameter when mature, markedly distended by the seeds; seeds 2-4, globose-ovoid, 1.8-2.8 mm long, light brown, finely reticulate. Chromosome number: $n=6$ (Chuang \& Constance, 1977; this study). 
Habitat and Distribution (Figure 13). Phacelia ranunculacea is found on the shaded rich soils of floodplains and the adjacent slopes of alluvial woods. The range is centered about southeastern Missouri and includes western Kentucky, western Tennessee, southern Illinois, southern Indiana, northeastern Mississippi, and most of Arkansas. Reports of P. ranunculacea from Jackson County, Illinois, Stewart County, Tennessee, and Clark and Poinsett counties in Arkansas (U.S.D.A., 2002) are included in the overall distribution of the complex (Figure 1). However, without specimens to verify the identifications they are omitted from the distribution map of the two species (Figure 13). Phenology. Phacelia ranunculacea flowers in late March to mid April, with fruit set immediately following. The seeds fall soon thereafter, upon desiccation and dehiscence of the capsule.

Notes. The collection by Nuttall is a mixture of Ellisia ranunculacea (= Phacelia ranunculacea) and Ellisia microcalyx (= Nemophila microcalyx), and the resulting confusion is understandable considering the remarkable resemblance of these two species. This led to the application of Nemophila microcalyx to both taxa (Gray, 1875) until Constance (1940) transferred Ellisia ranunculacea to the genus Phacelia. Phacelia ranunculacea is nearly identical to $P$. covillei except for several subtle but uniform characters. There are differences in the type and arrangement of hairs/glandular trichomes along the stem that are most obvious on the portion approximately halfway up the main axis of the plant. Phacelia covillei has mostly appressed/strigose hairs with a sparse arrangement of short $(<2 \mathrm{~mm})$ glandular trichomes, compared with $P$.

ranunculacea which has spreading/pilose hairs with more dense configuration of longer glandular trichomes. The shape of the terminal leaflet on the upper cauline leaves also exhibits minute differences. Phacelia covillei has acute leaf bases that range from cuneate to attentuate in shape, while the leaf bases of $P$. ranunculacea are obtuse and rounded to almost truncate. The terminal leaflets of some of the specimens examined had basal angles very close to $90^{\circ}$, even a couple a few degrees smaller. This was most notable for individuals from populations in the following counties: Hickman (KY), Montgomery (TN), Independence (AR), and Hempstead (AR). Remarkably the terminal leaflets of these specimens were twice as long as wide and lacked any secondary sinuses, 
both characteristics that deviate considerably from the averages for the $n=6$ cytotype. Nonetheless, designating these individuals as $P$. ranunculacea is appropriate given the unambiguous stem pubescence and the fact that two collections from the aforementioned counties served as chromosome vouchers (see Appendix B). Though two taxa may share the same habitat and occur in the same state, the chromosome number discrepancies and allopatric distribution seem to suggest the two have been separate entities for a substantial amount of time.

As is the case for $P$. covillei, the overall scarcity and narrow microhabitat parameters suggest the conservation status given to $P$. ranunculacea is appropriate. The local abundance of some populations and the addition of two county records during the course of this study belie the need for continued monitoring of $P$. ranunculacea throughout its range. Phacelia ranunculacea is listed as a species of "special concern" in Kentucky (Warren et. al., 1986) and Tennessee (Somers, 1989). Conservation efforts will need to be focused on states in which $P$. ranunculacea and $P$. covillei both occur. Indiana lists $P$. ranunculacea as endangered (Bacone \& Hedge, 1979) based on populations in Vanderburgh, Pike, and Knox counties. However, the populations studied in Pike and Knox counties are P. covillei and will need to be assessed separately from the Vanderburgh county populations. Neither Illinois nor Missouri list P. ranunculacea as threatened or endangered, which may be warranted given the number of populations relative to other states, but a single occurrence of $P$. covillei in each state highlights the need for further investigation. 


\section{LITERATURE CITED:}

Bacone, J.A. \& C.L. Hedge. 1979. A preliminary list of endangered and threatened vascular plants in Indiana. Proceedings of the Indiana Academy of Science. 89: 359- 371.

Baillon, H.E. 1890. Hydrophyllaceae. In: Histoire des plantes. L. Hatchette \& Co., Paris. 10:397-402.

Bentham, G. \& J.D. Hooker. 1876. Genera plantarum, vol. 2. Williams and Norgate, London.

Brand, A. 1913. Hydrophyllaceae. In: Engler, A. Das Pflanzenreich. 59 (IV: 251): 1-210.

Brown, R. 1810. Prodromus florae novae hollandiae, vol. 1. J. Johnson \& Co., London.

Cave, M. \& Constance, L. 1947. Chromosome numbers in the Hydrophyllaceae: III. University of California Publications in Botany. 18: 449-465.

Cave, M. \& Constance, L. 1950. Chromosome numbers in the Hydrophyllaceae: IV. University of California Publications in Botany. 23: 363-382.

Chuang, T. \& Constance, L. 1977. Cytogeography of Phacelia ranunculacea (Hydrophyllaceae). Rhodora. 79(817): 115-122.

Constance, L. 1939. The genera of the tribe Hydrophylleae of the Hydrophyllaceae. Madroño. 5(1): 28-33.

Constance, L.1940. The genus Ellisia. Rhodora. 42: 33-39.

Constance, L. 1949. A revision of Phacelia subgenus Cosmanthus (Hydrophyllaceae). Contributions to the Gray Herbarium. 168: 1-48.

Constance, L. 1950. Some interspecific relationships in Phacelia subgenus Cosmanthus. Proceedings of the American Academy of Arts and Science. 78: 135-147.

Constance, L. 1963. Chromosome number and classification in Hydrophyllaceae. Brittonia. 15: 273-285.

Constance, L. \& T.I. Chuang. 1982. SEM survey of pollen morphology and classification in Hydrophyllaceae (Waterleaf Family). American Journal of Botany. 69: 40-53.

Cronquist, A. 1981. An integrated system of classification of flowering plants. Columbia University Press, New York. 
Cronquist, A. 1988. The Evolution and Classification of Flowering Plants, $2^{\text {nd }}$ edition. The New York Botanical Garden, Bronx.

Cronquist, A., A.H. Holmgren, N.H. Holmgren, J.L. Reveal \& P.K. Holmgren. 1984. Intermountain Flora- vascular plants of the intermountain West, U.S.A. Vol. 4. The New York Botanical Garden, Bronx.

Ferguson, D.M. 1999. Phylogenetic Analysis of Relationships in Hydrophyllaceae based on $n d h F$ sequence data. Systematic Botany. 23(3): 253-268.

Gillett, G.W. 1964. Genetic barriers in the Cosmanthus phacelias (Hydrophyllaceae). Rhodora. 66: 359-368.

Gillett, G.W. 1968. Systematic relationships in the Cosmanthus phacelias (Hydrophyllaceae). Brittonia. 20: 368-374.

Gleason, H.A. 1903. A second Illinois station for Phacelia covillei Watson. Bulletin of the Torrey Botanical Club. 3: 89-90.

Gleason, H.A. \& A. Cronquist. 1991. Manual of the vascular plants of northeastern United States and adjacent Canada, ed. 2. The New York Botanical Garden, Bronx.

Gray, A. 1875. A conspectus of the North American Hydrophyllaceae. Proceedings of the American Academy of Arts and Sciences. 10: 312-332.

Gray, A., S. Watson \& J.M. Coulter. 1890. Manual of the botany of the northern United States..., ed. 6. American Book Company, New York.

Harvill, A.M. 1969. Virginia species with disjunct populations in the Middle West. Castanea. 34: 225-229.

Johansen, D.A. 1940. Plant Microtechnique. McGraw-Hill Co., Inc., New York.

Jussieu, A.L. De. 1789. Genera plantarum secundum ordines naturales disposita, $1^{\text {st }}$ ed. Herissant and Barrois, Paris.

K.S.N.P.C.(Kentucky State Nature Preserves Commission). 2000. Rare and extirpated biota of Kentucky. Journal of the Kentucky Academy of Science. 61(2): 115-132.

Lindley, J. 1836. A natural system of botany, $2^{\text {nd }}$ edition. Longman, Rees, Oram, Green, and Longman, London.

M.N.H.P.(Maryland Natural Heritage Program). 1988. Rare, threatened, and endangered plants of Maryland. Department of Natural Resources, Annapolis, MD. 
Murdy, W.H. 1966. The systematics of Phacelia maculata and P. dubia var. georgiana, Both endemic granite outcrop communities. American Journal of Botany. 53: 1028-1036.

Nuttall. 1837. Ellisia ranunculacea. Transactions of the American Philosophical Society, N.S. 5: 191.

Ohio Division of Natural Areas and Preserves. 2002. Rare native Ohio plants: 2002-03 status list. Ohio Department of Natural Resources, Columbus, OH.

Radford, A.E., W.C. Dickinson, J.R. Massey \& C.R. Bell. 1974. Vascular Plant Systematics. Harper \& Row Publ., New York.

Rohlf, F.J. 2002. NTSYS-pc version 2.11p Numerical Taxonomy and Multivariate Analysis System version 2.11p. Exeter Software, Setauket, NY.

Sass, J.E. 1958. Botanical Microtechnique. Iowa State College Press, Ames, Iowa.

Solbrig, O. 1970. Principles and methods of plant biosystematics. MacMillen, New York.

Somers, P. 1989. Revised list of the rare plants of Tennessee. Journal of the Tennessee Academy of Science. 64: 179-184.

Sutter, R.D., L. Mansberg \& J. Moore. 1983. Endangered, threatened, and rare plant species of North Carolina: A revised list. Bull. Assoc. Southeastern Biol. 30: 153-163.

Thorne, R.F. 1976. A phylogenetic classification of the angiosperms. Evolutionary Biology. 9: 35-106.

Turner, B.L. 1991. New species of Mexican Phacelia, Subgenus Cosmanthus (Hydrophyllaceae). Phytologia. 71(6): 445-452.

U.S.D.A., N.R.C.S. 2002. The PLANTS Database, Version 3.5. National Plant Center Data Center, Baton Rouge, LA 70874-4490 U.S.A. (http://plants.usda.gov).

Walters, D.R. \& D.J. Keil. 1975. Vascular Plant Taxonomy, $4^{\text {th }}$ edition. Kendall Hunt Publ. Co., Dubuque, Iowa.

Weakley, A.S. Flora of the Carolinas, Virginia, and Geogria. Working draft: September 26, 2003 (http//www.herbarium.unc.edu/weakley_flora). 


\begin{tabular}{|c|c|c|}
\hline Characters & Abbreviation & Character states \\
\hline \multicolumn{3}{|l|}{ Vegetative characters } \\
\hline \multicolumn{3}{|l|}{ 1.number of leaflets per terminal } \\
\hline \multicolumn{3}{|l|}{ 2.number of secondary sinuses } \\
\hline 3.terminal leaflet length & tlftlgh & $(\mathrm{mm})$ \\
\hline 4.terminal leaflet width & tlftwid & (mm) \\
\hline $\begin{array}{l}\text { 5.terminal leaflet length/width } \\
\text { ratio }\end{array}$ & lghwidratio & ratio (decimal to hundredth’s) \\
\hline 6.terminal leaflet basal angle & basalang & to nearest whole degree \\
\hline 7.terminal leaflet petiole length & petlgh & $(\mathrm{mm})$ \\
\hline \multicolumn{3}{|l|}{ 8.number of lobes per apical } \\
\hline $\begin{array}{l}\text { 9.number of lobes per basal } \\
\text { pinnatifid leaflet }\end{array}$ & numbalob & number \\
\hline 10.midstem pubescence & midstmpub & $0=$ strigose; 1 =pilose/retorse \\
\hline 11.midstem glandular trichomes & midstmgld & $0=$ short/sparse; $1=$ long/dense \\
\hline 12.terminal leaflet petiole indument* & petind & $0=$ glabrous; $1=$ pubescent \\
\hline 13.terminal leaflet petiole glands* & petgland & $0=$ absent; $1=$ present \\
\hline 14.adaxial laminar indument* & adlaind & $0=$ glabrous; $1=$ pubescent \\
\hline 15.adaxial laminar glands* & adlagland & $0=$ absent; $1=$ present \\
\hline 16.abaxial laminar indument* & ablaind & $0=$ glabrous; $1=$ pubescent \\
\hline 17.abaxial laminar glands* & ablagland & $0=$ absent; $1=$ present \\
\hline 18.primary peduncle indument* & pedunind & $0=$ glabrous $0=$ pubescent \\
\hline 19.primary peduncle glands* & pedungland & $0=$ absent; 1 =present \\
\hline 20.pedicel indument* & pedind & $0=$ glabrous; $1=$ pubescent \\
\hline 21.pedicel glandular trichomes* & pedgltr & $0=$ absent; $1=$ present \\
\hline \multicolumn{3}{|l|}{ Floral characters } \\
\hline 22.style length & stylgh & $(\mathrm{mm})$ \\
\hline 23.style division length & clflgh & (mm) \\
\hline 24.corolla lobe width & corlobwid & $(\mathrm{mm})$ \\
\hline 25.corolla lobe length & corloblgh & (mm) \\
\hline 26.corolla length & corlgh & (mm) \\
\hline 27.filament length & fillgh & $(\mathrm{mm})$ \\
\hline 28.anther length & anthlgh & $(\mathrm{mm})$ \\
\hline 29.anther width & anthwid & (mm) \\
\hline 30.nectar flap length & ncflplgh & (mm) \\
\hline 31.sepal length & seplgh & $(\mathrm{mm})$ \\
\hline 32.sepal width & sepwid & (mm) \\
\hline 33.corolla lobe width/length ratio & loberatio & ratio (to nearest hundredth’s) \\
\hline 34.style length/division ratio & styclfratio & ratio (to nearest hundredth's) \\
\hline 35.sepal indument* & sepind & $0=$ glabrous; $1=$ pubescent \\
\hline 36.sepal glandular trichomes* & sepgltr & $0=$ absent; $1=$ present \\
\hline 37.filament indument* & filind & $(\mathrm{mm})$ \\
\hline 38.ovary indument* & ovaind & $0=$ glabrous; $1=$ pubescent \\
\hline
\end{tabular}

Table 1. Morphological characters, acronyms, and the values assigned to each character state used in the NTSys-PC 2.1 analysis of Phacelia ranunculacea s.l. (*characters with an asterisk were not variable and not entered in the dataset). 


\begin{tabular}{|c|c|c|c|c|c|c|c|c|c|c|c|c|c|}
\hline $\begin{array}{c}\text { "Eastern" } n=14 \\
\text { cytotype }\end{array}$ & $\begin{array}{c}22 . \\
\text { stylgh }\end{array}$ & $\begin{array}{l}23 . \\
\text { clflgh }\end{array}$ & $\begin{array}{c}24 . \\
\text { corlobwid }\end{array}$ & $\begin{array}{c}25 . \\
\text { corloblgh }\end{array}$ & $\begin{array}{c}26 . \\
\text { corlgh }\end{array}$ & $\begin{array}{c}27 . \\
\text { fillgh }\end{array}$ & $\begin{array}{c}28 . \\
\text { anthlgh }\end{array}$ & $\begin{array}{c}29 . \\
\text { anthwid }\end{array}$ & $\begin{array}{c}30 . \\
\text { ncflplgh }\end{array}$ & $\begin{array}{c}31 . \\
\text { seplgh }\end{array}$ & $\begin{array}{c}32 . \\
\text { sepwid }\end{array}$ & $\begin{array}{c}33 . \\
\text { loberatio } \\
\end{array}$ & $\begin{array}{c}34 . \\
\text { styclfratio }\end{array}$ \\
\hline Mean & 1.5081 & 0.7203 & 1.74677 & 1.42193 & 4.3035 & 1.8387 & 0.4484 & 0.3903 & 0.36452 & 3.7997 & 0.7568 & 1.23 & 2.16258 \\
\hline Standard Error & 0.0505 & 0.0344 & 0.05729 & 0.03779 & 0.0845 & 0.0447 & 0.0123 & 0.0111 & 0.00905 & 0.0985 & 0.0208 & 0.02829 & 0.07544 \\
\hline Median & 1.5 & 0.7 & 1.76 & 1.41 & 4.41 & 1.87 & 0.43 & 0.37 & 0.36 & 3.72 & 0.76 & 1.22 & 2.16 \\
\hline Mode & 1.77 & 0.82 & 1.97 & 1.24 & 4.02 & 1.79 & 0.42 & 0.36 & 0.39 & 3.3 & 0.83 & 1.27 & 2.23 \\
\hline Standard Deviation & 0.281 & 0.1915 & 0.31897 & 0.21041 & 0.4703 & 0.2489 & 0.0683 & 0.062 & 0.05039 & 0.5484 & 0.1156 & 0.15752 & 0.42003 \\
\hline Sample Variance & 0.0789 & 0.0367 & 0.10174 & 0.04427 & 0.2212 & 0.062 & 0.0047 & 0.0038 & 0.00254 & 0.3007 & 0.0134 & 0.02481 & 0.17643 \\
\hline Range & 1.27 & 0.96 & 1.5 & 0.87 & 1.74 & 0.96 & 0.28 & 0.21 & 0.2 & 2.06 & 0.47 & 0.6 & 2.09 \\
\hline Minimum & 0.93 & 0.37 & 1.02 & 0.96 & 3.24 & 1.26 & 0.36 & 0.32 & 0.29 & 2.62 & 0.47 & 1.03 & 1.5 \\
\hline Maximum & 2.2 & 1.33 & 2.52 & 1.83 & 4.98 & 2.22 & 0.64 & 0.53 & 0.49 & 4.68 & 0.94 & 1.63 & 3.59 \\
\hline Sum & 46.75 & 22.33 & 54.15 & 44.08 & 133.41 & 57 & 13.9 & 12.1 & 11.3 & 117.79 & 23.46 & 38.13 & 67.04 \\
\hline Count & 31 & 31 & 31 & 31 & 31 & 31 & 31 & 31 & 31 & 31 & 31 & 31 & 31 \\
\hline $\begin{array}{c}\text { "Western" n=6 } \\
\text { cytotype }\end{array}$ & $\begin{array}{c}22 . \\
\text { stylgh }\end{array}$ & $\begin{array}{l}23 . \\
\text { clflgh }\end{array}$ & $\begin{array}{c}24 . \\
\text { corlobwid }\end{array}$ & $\begin{array}{c}25 . \\
\text { corloblgh }\end{array}$ & $\begin{array}{c}26 . \\
\text { corlgh }\end{array}$ & $\begin{array}{c}27 . \\
\text { fillgh }\end{array}$ & $\begin{array}{c}28 . \\
\text { anthlgh }\end{array}$ & $\begin{array}{c}29 . \\
\text { anthwid }\end{array}$ & $\begin{array}{c}30 . \\
\text { ncflplgh }\end{array}$ & $\begin{array}{c}31 . \\
\text { seplgh }\end{array}$ & $\begin{array}{c}32 . \\
\text { sepwid }\end{array}$ & $\begin{array}{c}33 . \\
\text { loberatio }\end{array}$ & $\begin{array}{c}34 . \\
\text { styclfratio } \\
\end{array}$ \\
\hline Mean & 1.32 & 0.7913 & 1.33625 & 1.41416 & 4.0208 & 1.7754 & 0.3654 & 0.3417 & 0.28682 & 3.0408 & 0.8367 & 0.94958 & 1.78083 \\
\hline Standard Error & 0.0318 & 0.0398 & 0.05304 & 0.05322 & 0.1111 & 0.0513 & 0.0114 & 0.0084 & 0.00886 & 0.1072 & 0.0323 & 0.01912 & 0.08425 \\
\hline Median & 1.325 & 0.785 & 1.325 & 1.425 & 4.045 & 1.805 & 0.35 & 0.345 & 0.29 & 2.925 & 0.805 & 0.965 & 1.75 \\
\hline Mode & 1.33 & 0.61 & 1.15 & 1.43 & 3.97 & 1.85 & 0.33 & 0.34 & 0.31 & 2.58 & 0.69 & 1 & 1.75 \\
\hline Standard Deviation & 0.1556 & 0.1947 & 0.25985 & 0.26075 & 0.5441 & 0.2513 & 0.0558 & 0.0409 & 0.04156 & 0.5251 & 0.1584 & 0.09369 & 0.41277 \\
\hline Sample Variance & 0.0242 & 0.0379 & 0.06752 & 0.06799 & 0.2961 & 0.0631 & 0.0031 & 0.0017 & 0.00173 & 0.2757 & 0.0251 & 0.00878 & 0.17038 \\
\hline Range & 0.61 & 0.83 & 1.23 & 1.23 & 2.7 & 1.13 & 0.25 & 0.18 & 0.17 & 2.31 & 0.6 & 0.42 & 1.82 \\
\hline Minimum & 1.07 & 0.5 & 0.88 & 0.83 & 2.76 & 1.3 & 0.25 & 0.26 & 0.19 & 1.95 & 0.6 & 0.78 & 1.12 \\
\hline Maximum & 1.68 & 1.33 & 2.11 & 2.06 & 5.46 & 2.43 & 0.5 & 0.44 & 0.36 & 4.26 & 1.2 & 1.2 & 2.94 \\
\hline Sum & 31.68 & 18.99 & 32.07 & 33.94 & 96.5 & 42.61 & 8.77 & 8.2 & 6.31 & 72.98 & 20.08 & 22.79 & 42.74 \\
\hline Count & 24 & 24 & 24 & 24 & 24 & 24 & 24 & 24 & 22 & 24 & 24 & 24 & 24 \\
\hline
\end{tabular}

Table 2. Summary statistics of each floral character segregated into the two groups suggested by the results of the scatter plots, principle component analysis (PCA), and cluster (UPGMA) analyses. 


\begin{tabular}{|c|c|c|c|c|c|c|c|c|c|c|c|}
\hline $\begin{array}{c}\text { "Eastern" n=14 } \\
\text { cytotype }\end{array}$ & $\begin{array}{c}1 . \\
\text { numlfts }\end{array}$ & $\begin{array}{c}2 . \\
\text { numsintlft }\end{array}$ & $\begin{array}{c}3 . \\
\text { tlftlgh }\end{array}$ & $\begin{array}{c}4 . \\
\text { tlftwid }\end{array}$ & $\begin{array}{c}5 . \\
\text { Ighwidratio }\end{array}$ & $\begin{array}{c}6 . \\
\text { basalang } \\
\end{array}$ & $\begin{array}{c}7 . \\
\text { petlgh }\end{array}$ & $\begin{array}{c}8 . \\
\text { numaplob }\end{array}$ & $\begin{array}{c}9 . \\
\text { numbalob }\end{array}$ & $\begin{array}{c}10 . \\
\text { midstmpub }\end{array}$ & $\begin{array}{c}11 . \\
\text { midstmgld }\end{array}$ \\
\hline Mean & 2.994949 & 1.020202 & 15.49495 & 10.31667 & 1.510859 & 69.69192 & 6.566061 & 1.635417 & 1.443299 & 0 & 0 \\
\hline Standard Error & 0.033964 & 0.077109 & 0.404318 & 0.267779 & 0.012262 & 0.556093 & 0.245989 & 0.060556 & 0.058441 & 0 & 0 \\
\hline Median & 3 & 1 & 14.4 & 9.75 & 1.51 & 70 & 5.85 & 1 & 1 & 0 & 0 \\
\hline Mode & 3 & 0 & 18.5 & 10.9 & 1.51 & 74 & 6 & 1 & 1 & 0 & 0 \\
\hline Standard Deviation & 0.477913 & 1.085014 & 5.689261 & 3.767989 & 0.172547 & 7.824927 & 3.461374 & 0.839094 & 0.813985 & 0 & 0 \\
\hline Sample Variance & 0.228401 & 1.177255 & 32.36769 & 14.19774 & 0.029772 & 61.22948 & 11.98111 & 0.704079 & 0.662571 & 0 & 0 \\
\hline Range & 4 & 4 & 29.8 & 18.2 & 1.14 & 36 & 21.8 & 5 & 3 & 0 & 0 \\
\hline Minimum & 1 & 0 & 5.4 & 3.2 & 1.08 & 52 & 1.2 & 0 & 0 & 0 & 0 \\
\hline Maximum & 5 & 4 & 35.2 & 21.4 & 2.22 & 88 & 23 & 5 & 3 & 0 & 0 \\
\hline Sum & 593 & 202 & 3068 & 2042.7 & 299.15 & 13799 & 1300.08 & 314 & 280 & 0 & 0 \\
\hline Count & 198 & 198 & 198 & 198 & 198 & 198 & 198 & 192 & 194 & 198 & 198 \\
\hline $\begin{array}{c}\text { "Western" n=6 } \\
\text { cytotype }\end{array}$ & $\begin{array}{c}1 . \\
\text { numlfts }\end{array}$ & $\begin{array}{c}2 . \\
\text { numsintlft }\end{array}$ & $\begin{array}{c}3 . \\
\text { tlftlgh }\end{array}$ & $\begin{array}{c}4 . \\
\text { tlftwid }\end{array}$ & $\begin{array}{c}5 . \\
\text { Ighwidratio } \\
\end{array}$ & $\begin{array}{c}6 . \\
\text { basalang } \\
\end{array}$ & $\begin{array}{c}7 . \\
\text { petlgh }\end{array}$ & $\begin{array}{c}8 . \\
\text { numaplob }\end{array}$ & $\begin{array}{c}9 . \\
\text { numbalob }\end{array}$ & $\begin{array}{c}10 . \\
\text { midstmpub }\end{array}$ & $\begin{array}{c}11 . \\
\text { midstmgld }\end{array}$ \\
\hline Mean & 2.781955 & 1.593985 & 17.0203 & 13.49398 & 1.282857 & 107.7895 & 9.165414 & 1.679389 & 1.560606 & 1 & 1 \\
\hline Standard Error & 0.048135 & 0.11094 & 0.49798 & 0.437297 & 0.015245 & 0.858133 & 0.431424 & 0.085514 & 0.092049 & 0 & 0 \\
\hline Median & 3 & 2 & 15.3 & 12.1 & 1.27 & 107 & 8 & 1 & 1 & 1 & 1 \\
\hline Mode & 3 & 2 & 13.8 & 11.6 & 1.24 & 96 & 6 & 1 & 1 & 1 & 1 \\
\hline Standard Deviation & 0.555119 & 1.279427 & 5.74299 & 5.043159 & 0.175817 & 9.896474 & 4.975425 & 0.978753 & 1.057561 & 0 & 0 \\
\hline Sample Variance & 0.308157 & 1.636933 & 32.98193 & 25.43345 & 0.030911 & 97.94019 & 24.75486 & 0.957957 & 1.118436 & 0 & 0 \\
\hline Range & 2 & 6 & 27.9 & 25.8 & 0.9 & 47 & 25.1 & 4 & 5 & 0 & 0 \\
\hline Minimum & 1 & 0 & 5.7 & 4.9 & 0.81 & 91 & 2.4 & 0 & 0 & 1 & 1 \\
\hline Maximum & 3 & 6 & 33.6 & 30.7 & 1.71 & 138 & 27.5 & 4 & 5 & 1 & 1 \\
\hline Sum & 370 & 212 & 2263.7 & 1794.7 & 170.62 & 14336 & 1219 & 220 & 206 & 133 & 133 \\
\hline Count & 133 & 133 & 133 & 133 & 133 & 133 & 133 & 131 & 132 & 133 & 133 \\
\hline
\end{tabular}

Table 3. Summary statistics of each vegetative character segregated into the two groups suggested by the results of the scatter plots, principal component analysis (PCA), and the cluster (UPGMA) analyses. 


\begin{tabular}{|c|c|c|c|}
\hline Eigenvalues & 7.3806 & 3.8263 & 2.4621 \\
\hline Component loadings & C1 & C2 & C3 \\
\hline 1.numlfts & 0.4835 & 0.1176 & -0.5468 \\
\hline 2.numsintlft & -0.1423 & 0.4376 & -0.3396 \\
\hline 3.tlftlgh & -0.3475 & 0.5233 & 0.2800 \\
\hline 4.tlftwid & -0.4963 & 0.5215 & 0.3452 \\
\hline 5.Ighwidratio & 0.4435 & -0.1817 & -0.2849 \\
\hline 6.basalang & -0.7973 & 0.2355 & -0.0532 \\
\hline 7.petlgh & -0.4515 & 0.5058 & 0.2828 \\
\hline 8.numaplob & 0.1912 & 0.3048 & -0.7580 \\
\hline 9.numbalob & 0.1298 & 0.4021 & -0.6864 \\
\hline 10.midstmpub & -0.8587 & 0.2588 & -0.1006 \\
\hline 11.midstmgld & -0.8587 & 0.2588 & -0.1006 \\
\hline 22.stylgh & 0.5359 & 0.6019 & 0.2096 \\
\hline 23.clflgh & -0.0195 & 0.5860 & -0.2051 \\
\hline 24.corlobwid & 0.8316 & 0.3172 & 0.2082 \\
\hline 25.corloblgh & 0.4135 & 0.6587 & 0.0064 \\
\hline 26.corlgh & 0.6079 & 0.6236 & 0.1185 \\
\hline 27.fillgh & 0.3779 & 0.6251 & 0.0642 \\
\hline 28.anthlgh & 0.6759 & -0.1831 & -0.0002 \\
\hline 29.anthwid & 0.5569 & -0.1674 & -0.3320 \\
\hline 30.ncflplgh & 0.6696 & -0.0624 & 0.2376 \\
\hline 31.seplgh & 0.8069 & 0.3528 & 0.1146 \\
\hline 32.sepwid & -0.0768 & 0.2776 & 0.2872 \\
\hline 33.loberatio & 0.6960 & -0.2136 & 0.2259 \\
\hline 34.styclfratio & 0.4194 & -0.0996 & 0.3993 \\
\hline $\begin{array}{l}\text { Percent of total } \\
\text { variance explained }\end{array}$ & 30.7527 & 15.9429 & 10.2588 \\
\hline
\end{tabular}

Table 4. Eigenvectors and eigenvalues for the first three axes from Principal Components Analysis of $P$. ranunculacea s.l. The values were computed from floral and vegetative variables (both qualitative and quantitative). 


\begin{tabular}{|c|c|c|c|}
\hline Character & Test statistic & degrees of freedom $(\mathrm{d} f)^{1}$ & Probability value \\
\hline 1.Number of leaflets ${ }^{* *}$ & 3.6155 & 254 & 0.0004 \\
\hline 2.Number of $2^{\circ}$ sinuses $* *$ & 4.2469 & 251 & $3.0549 \mathrm{E}-5$ \\
\hline 3.Terminal leaflet length* & 2.3780 & 281 & 0.0181 \\
\hline 4.Terminal leaflet width** & 6.1964 & 228 & $2.6741 \mathrm{E}-9$ \\
\hline 5.Terminal leaflet length/width ratio** & 11.6536 & 280 & 7.5001E-26 \\
\hline 6.Basal angle ${ }^{* *}$ & 37.2570 & 238 & $2.7161 \mathrm{E}-101$ \\
\hline 7.Petiole length** & 5.2340 & 216 & $3.9208 \mathrm{E}-7$ \\
\hline 8.Lobes per apical leaflet & 0.4196 & 250 & 0.6751 \\
\hline 9.Lobes per basal leaflet & 1.0759 & 232 & 0.2831 \\
\hline 22.Style length** & 3.1537 & 49 & 0.0028 \\
\hline 23.Style cleft length & 1.3494 & 49 & 0.1834 \\
\hline 24.Corolla lobe width** & 5.2582 & 53 & $2.6584 \mathrm{E}-6$ \\
\hline 25.Corolla lobe length & 0.1190 & 44 & 0.9058 \\
\hline 26.Corolla length & 2.0260 & 46 & 0.0486 \\
\hline 27.Filament length & 0.9302 & 49 & 0.3568 \\
\hline 28.Anther length** & 4.9580 & 53 & $7.6968 \mathrm{E}-6$ \\
\hline 29.Anther width** & 3.4953 & 52 & 0.0010 \\
\hline 30.Nectar flap length** & 6.1344 & 50 & $1.3523 \mathrm{E}-7$ \\
\hline 31.Sepal length** & 5.2132 & 51 & 3.3937E-6 \\
\hline 32.Sepal width* & 2.0794 & 41 & 0.0439 \\
\hline 33.Corolla lobe ratio** & 8.2115 & 50 & $7.8470 \mathrm{E}-11$ \\
\hline 34.Style/cleft length ratio** & 3.3754 & 50 & 0.0014 \\
\hline
\end{tabular}

Table 5. Pairwise comparisons of the two groups produced via ordinate and clustering analyses using a two sample t-test based on separate variances. Statistically significant characters indicated at the $\alpha=0.05$ and $\alpha=0.01$ levels are based on probabilities of ${ }^{*} \mathrm{p}<0.05$ and $* * \mathrm{p}<0.01$ respectively. ( ${ }^{1}$ Degrees of freedom calculated via Welch/Satterthwaite method.) 


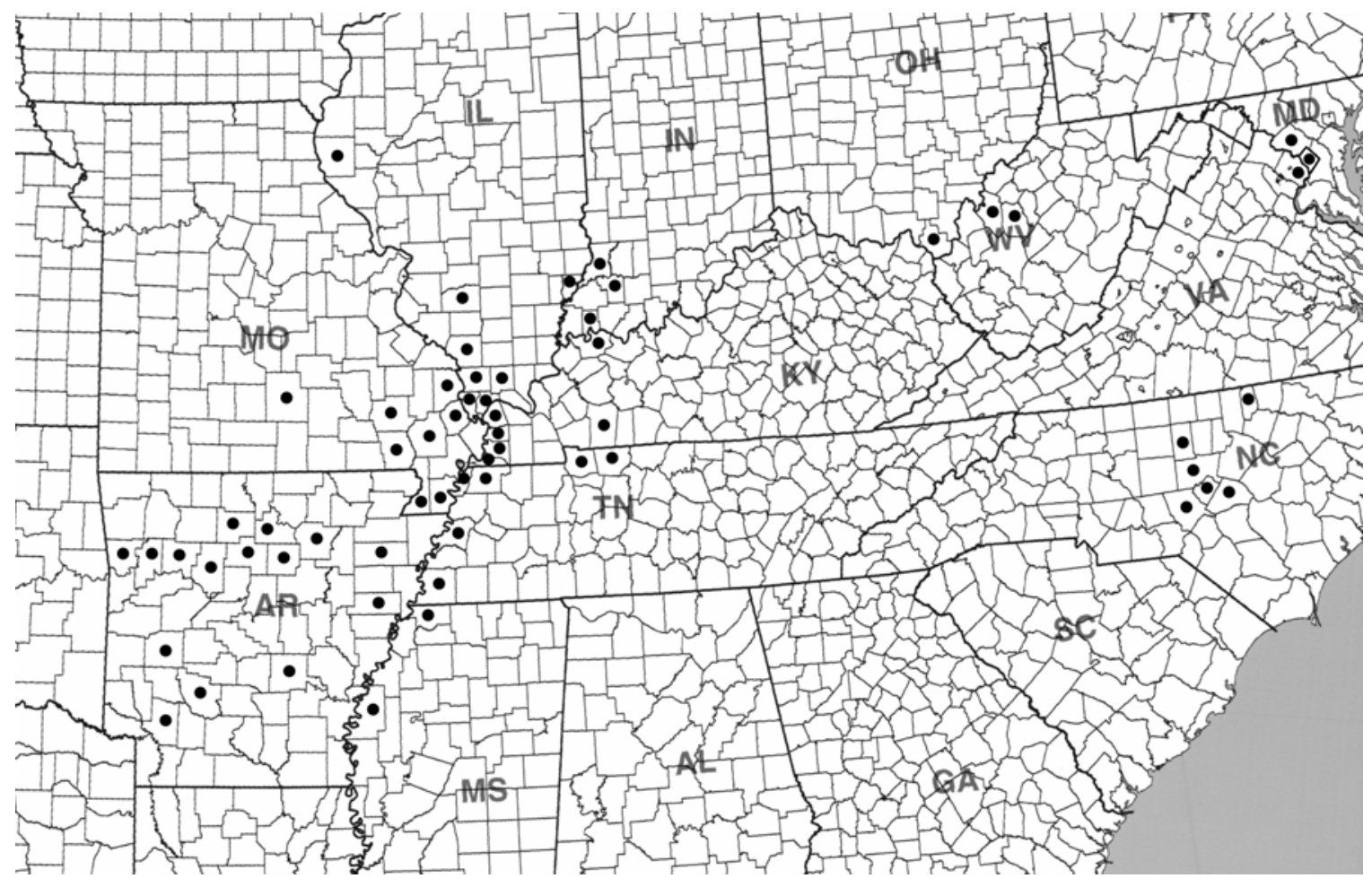

Figure 1. Geographic distribution of Phacelia ranunculacea s.l. 


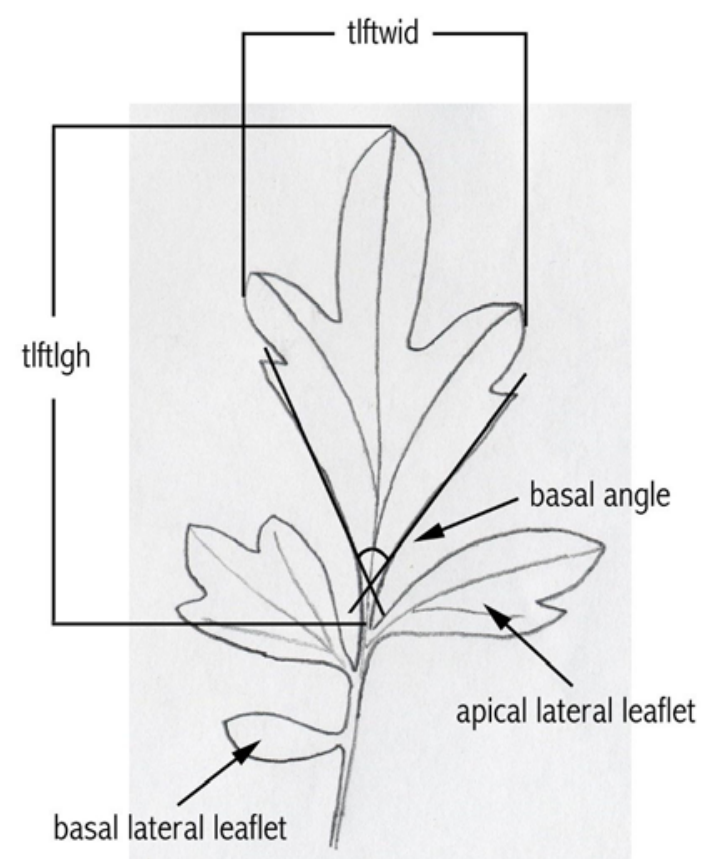

A.

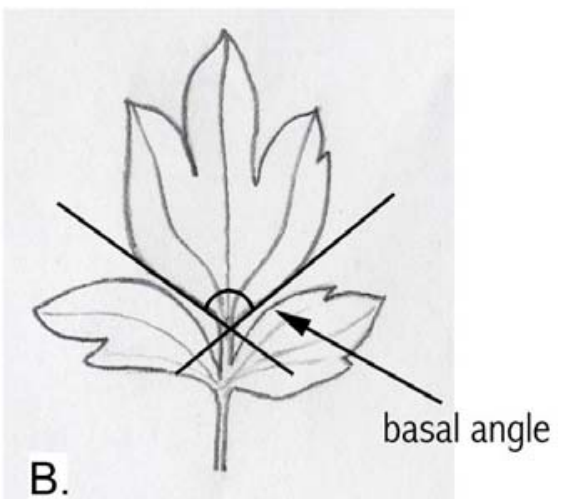

B.

Figure 2. Diagram of terminal leaf. 3.tlftlgh is terminal leaflet length and 4.tlftwid is terminal leaflet width. Basal angle (6.basalang) of terminal leaflet: A. acute B. obtuse.
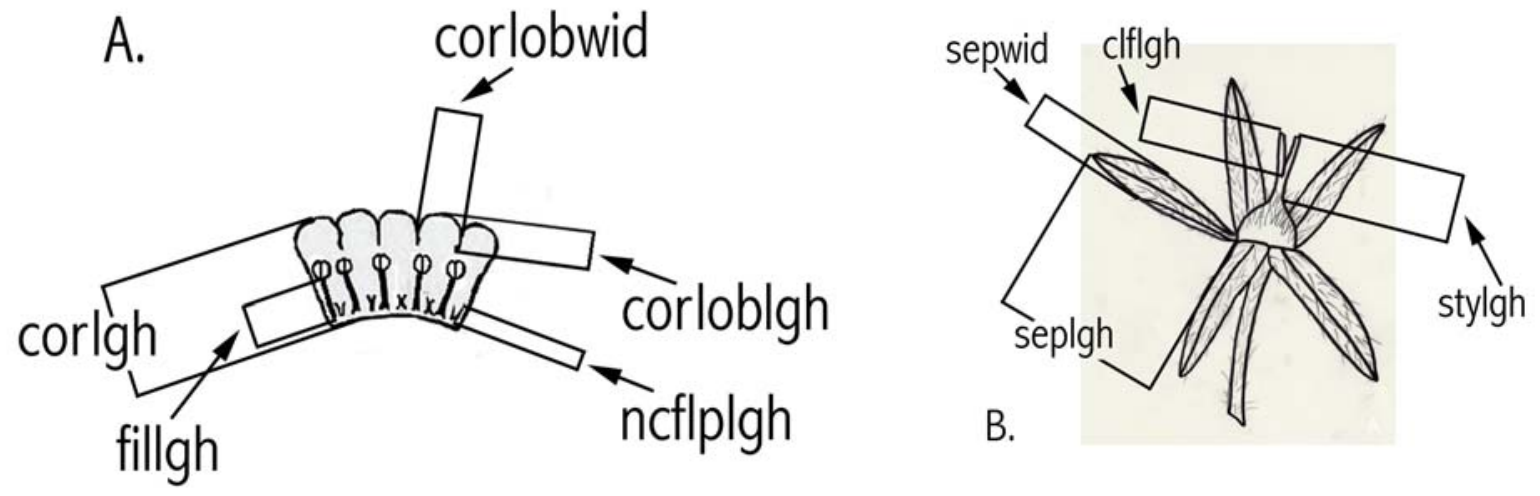

Figure 3. Floral diagrams (A. corolla and androecium and B. calyx and pistil) illustrating measurements. Refer to Table $\mathbf{1}$ for acronym explanations. 
A

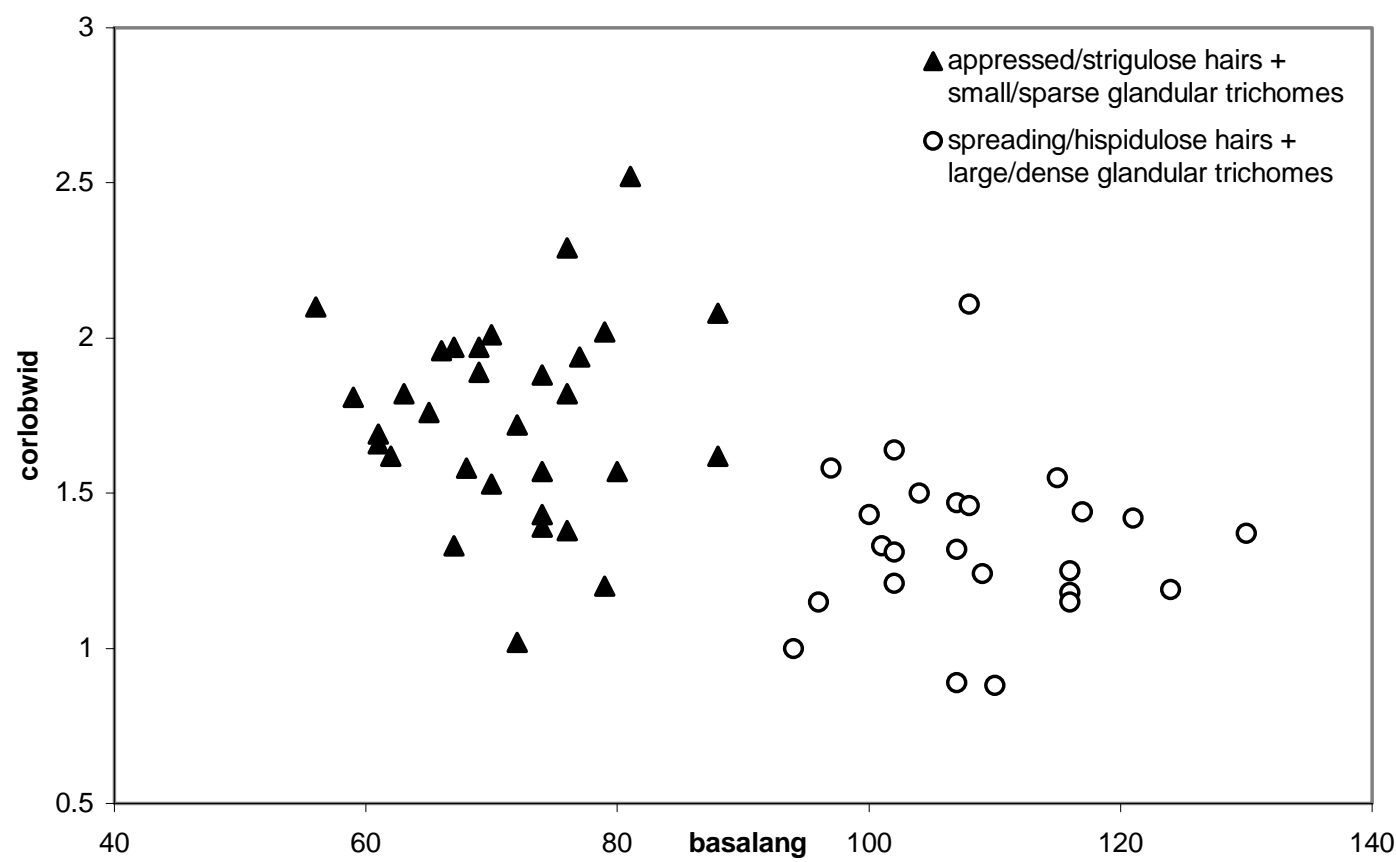

B

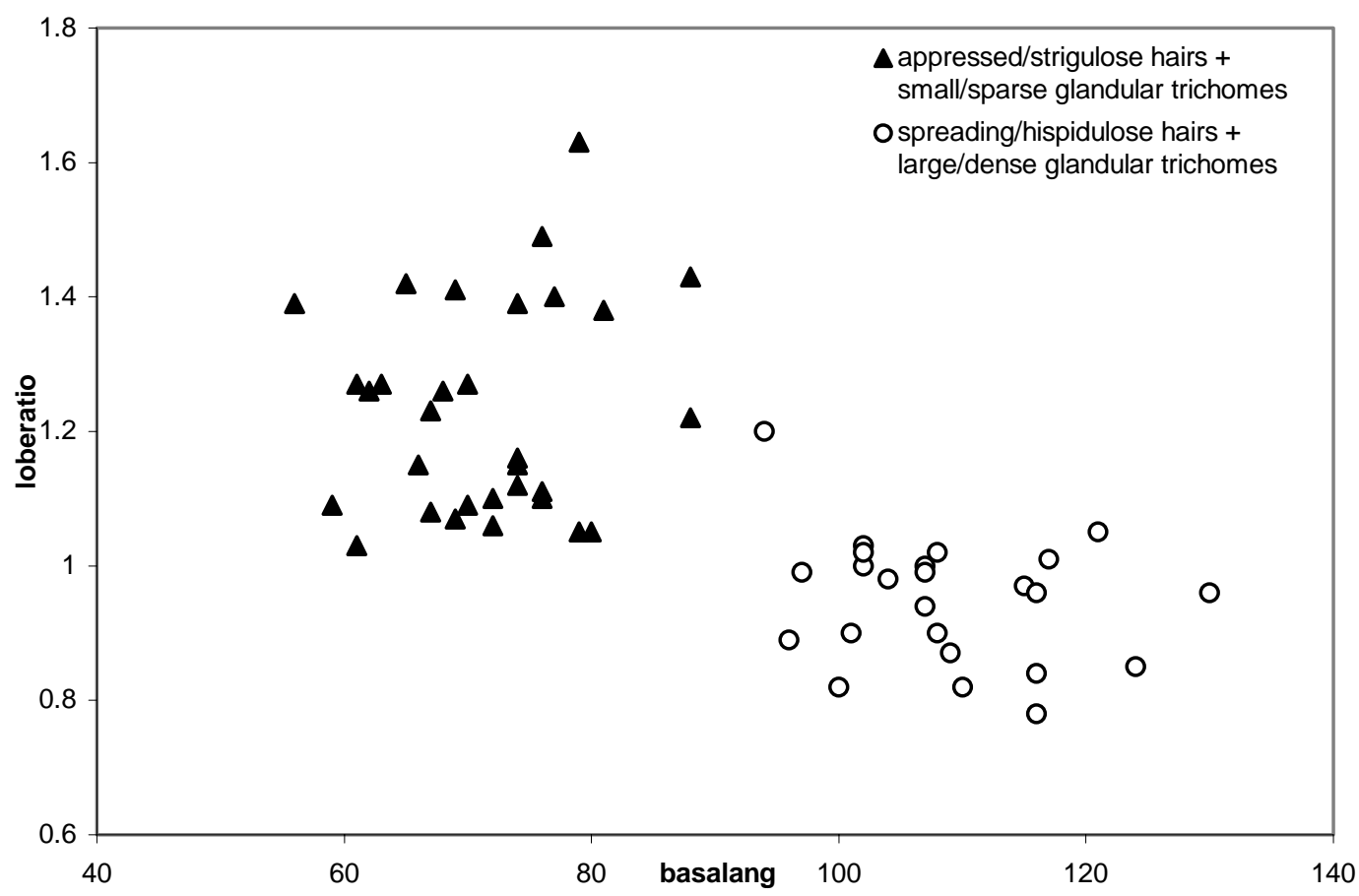

Figure 4. Bivariate scatter plots from floral and vegetative morphological analysis of Phacelia ranunculacea s.l. A. Terminal leaflet basal angle (6.basalang) versus corolla lobe width (24.corlobwid) (mm). B. Terminal leaflet basal angle (6.basalang) versus corolla lobe width/length ratio (33.loberatio). 
A

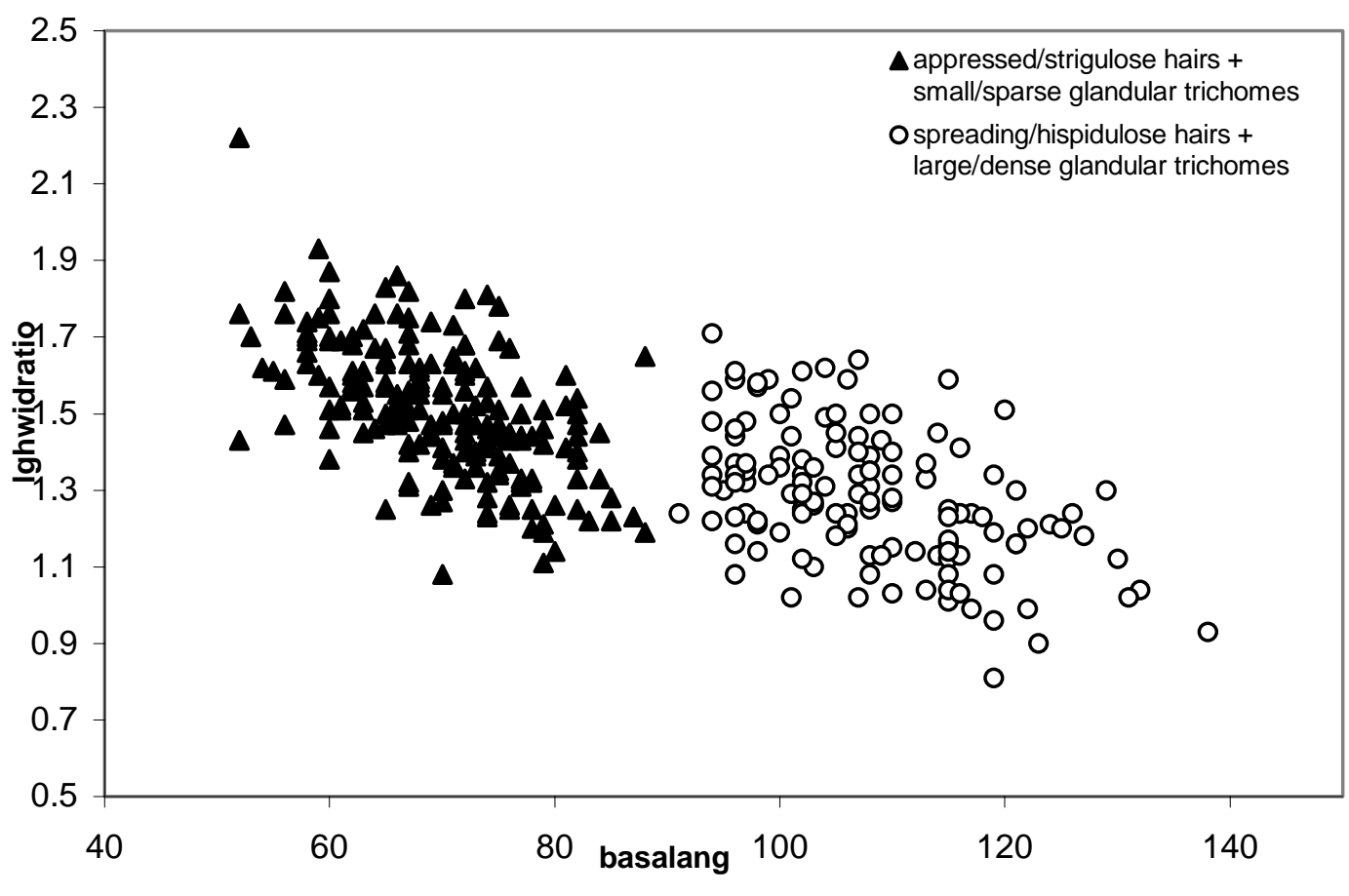

B

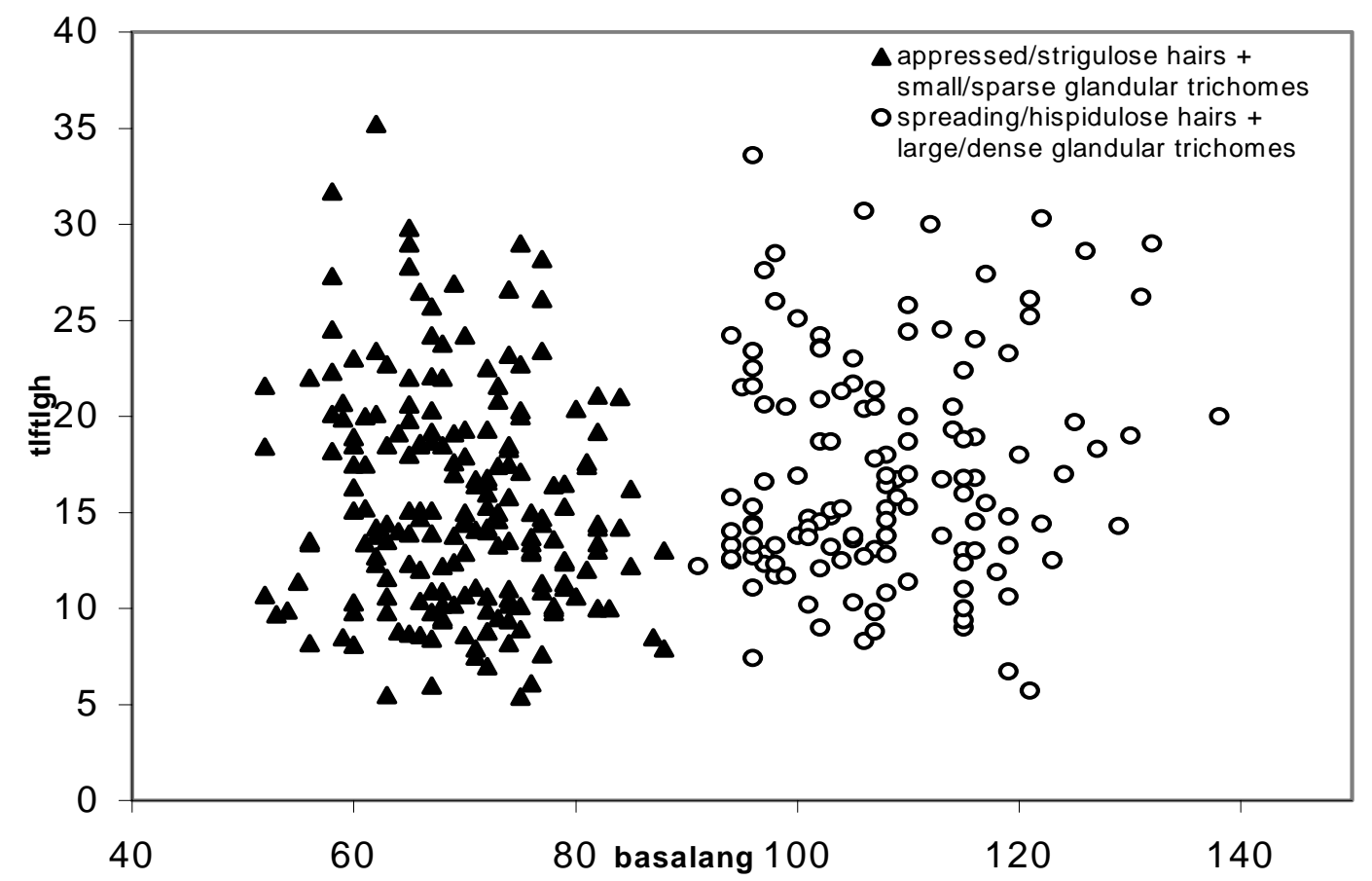

Figure 5. Bivariate scatter plots from vegetative morphological analysis of Phacelia ranunculacea s.l. A. Terminal leaflet basal angle (6.basalang) versus terminal leaflet length/width ratio (5.lghwidratio). B. Terminal leaflet basal angle (6.basalang) versus terminal leaflet length (3.tlftlgh) $(\mathrm{mm})$. 


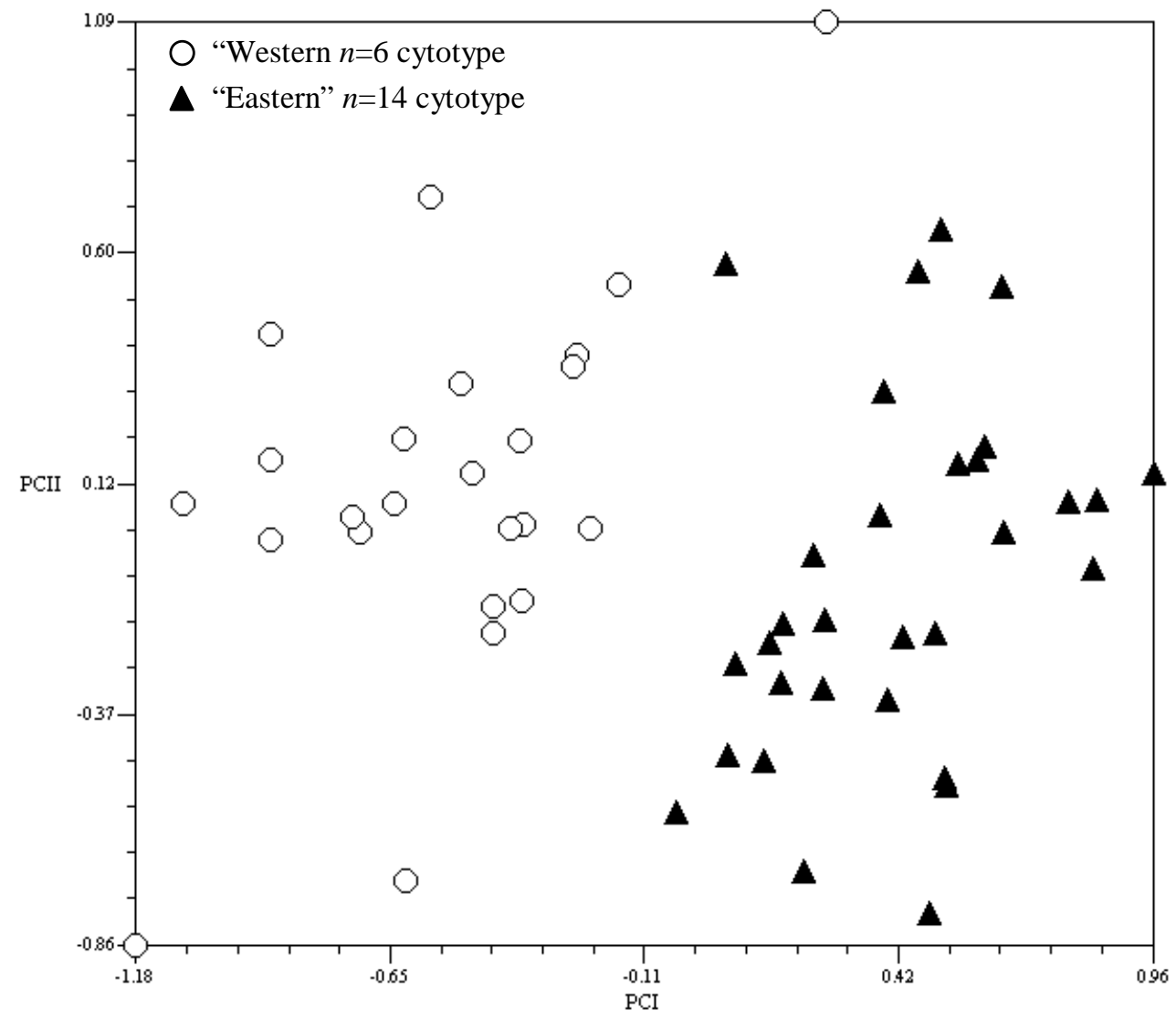

Figure 6. Plot of scores from principal component axes I and II computed from floral and vegetative data. 


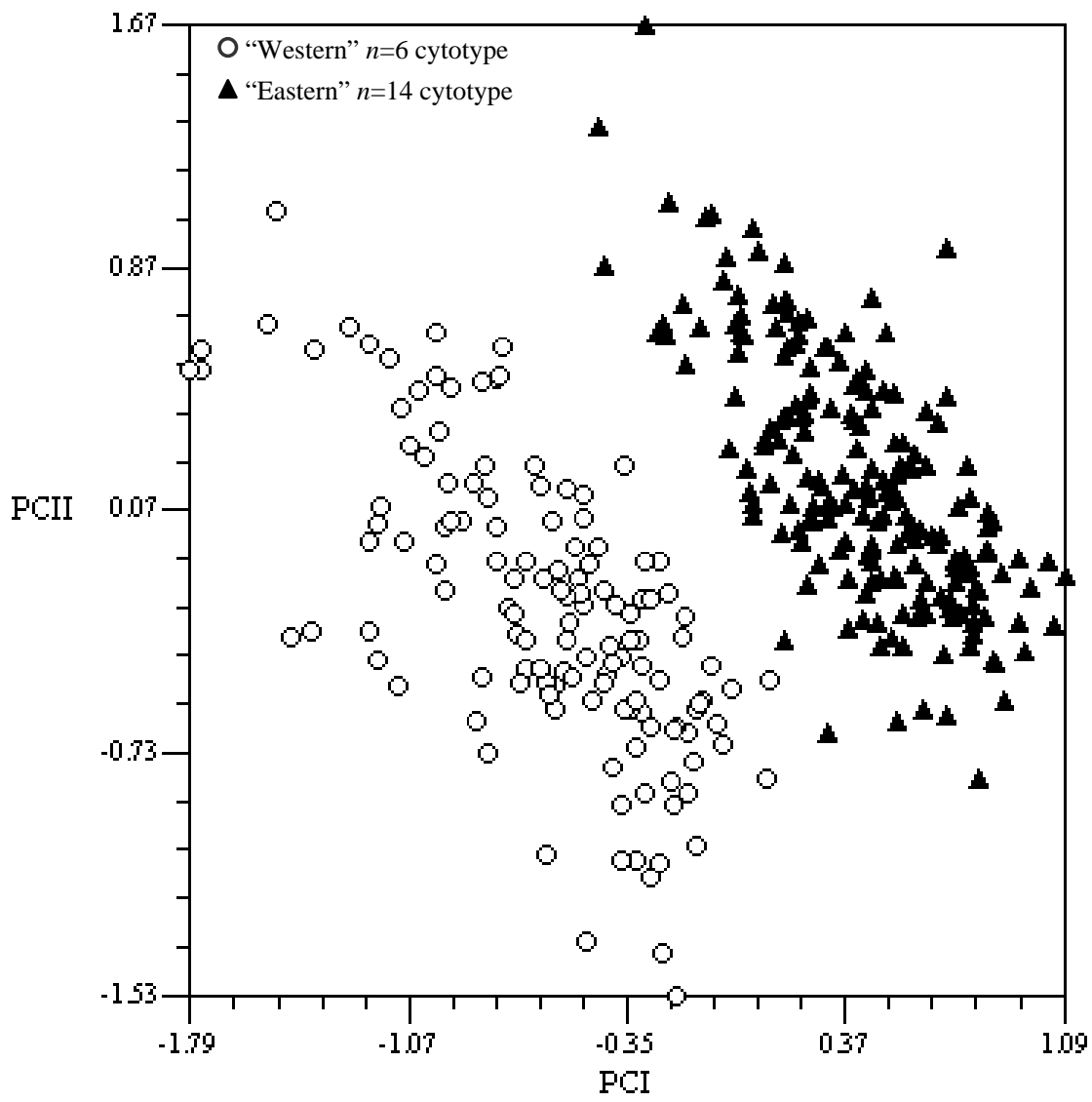

Figure 7. Plot of scores from principal component axes I and II computed from vegetative data. 


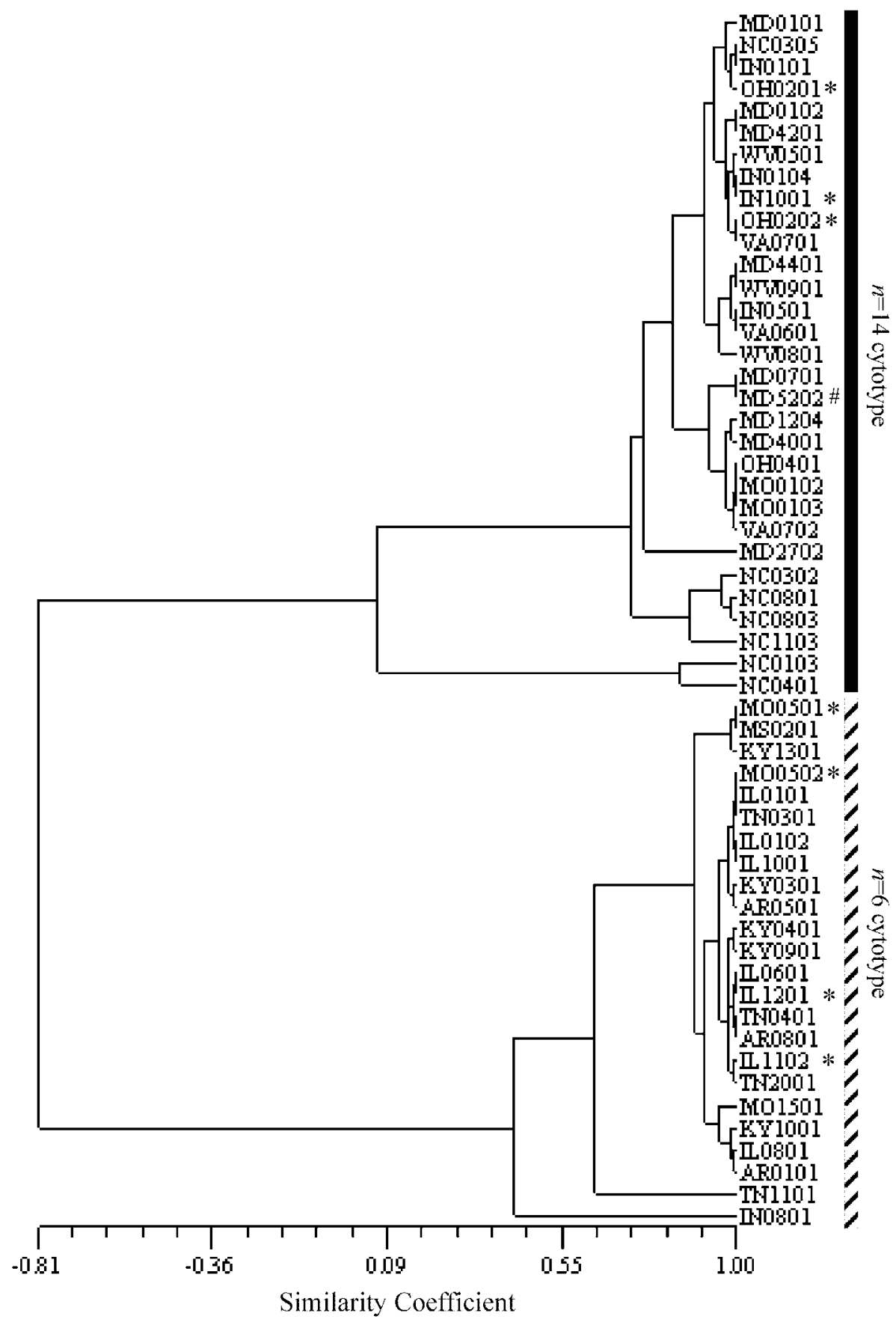

Figure 8. Phenogram of floral and vegetative morphological data showing two distinct groups corresponding to the chromosome counts. Cophenetic correlation coefficient $(r)=.9715$; * chromosome voucher, \# = type population of Phacelia covillei Wats. 


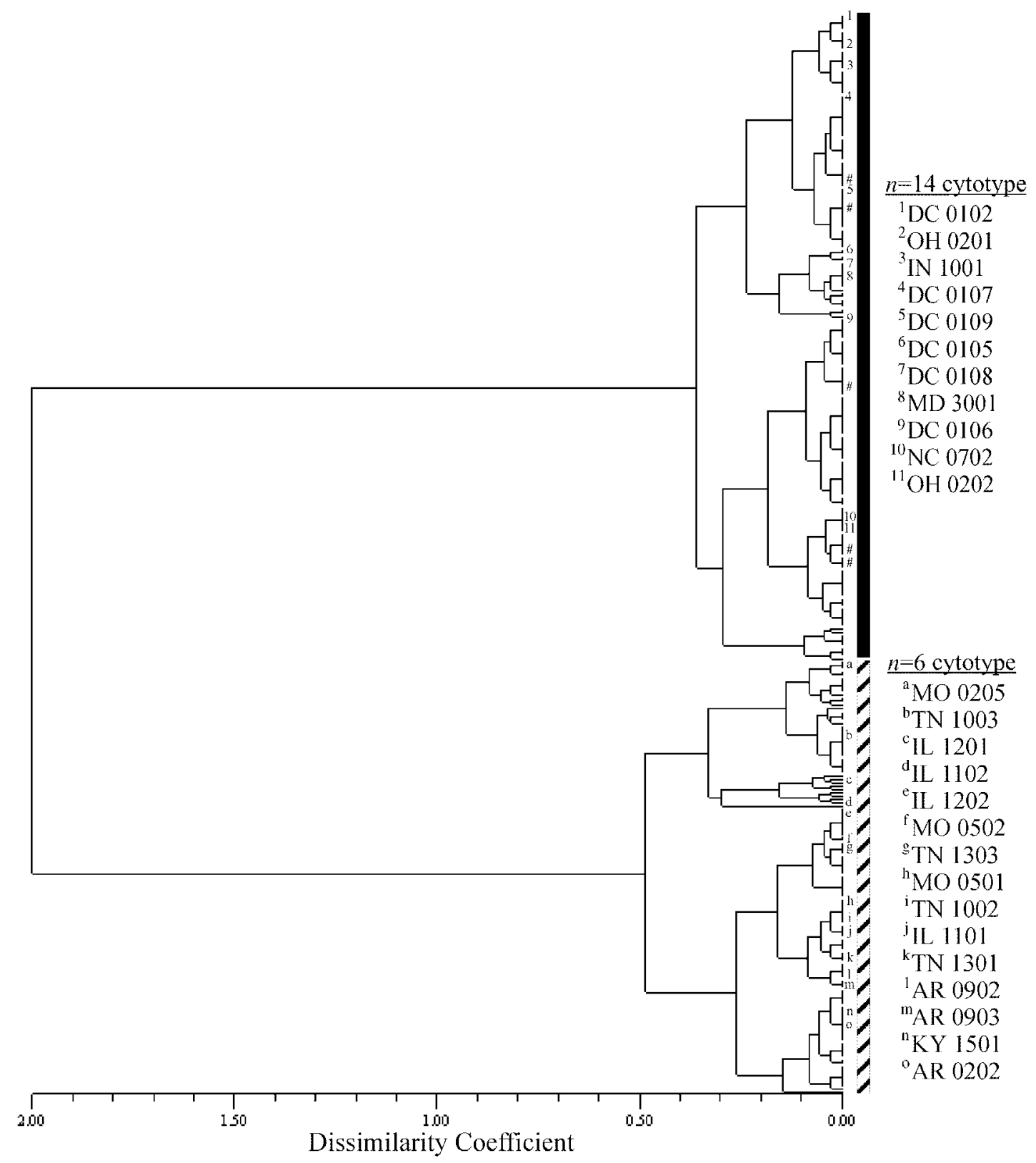

Figure 9. Phenogram of vegetative morphological data showing two distinct groups corresponding to the different chromosome numbers with the OTU codes for the voucher specimens noted (\# = OTUs from the type population of Phacelia covillei Wats). Cophenetic correlation coefficient $(r)=.9819$. 

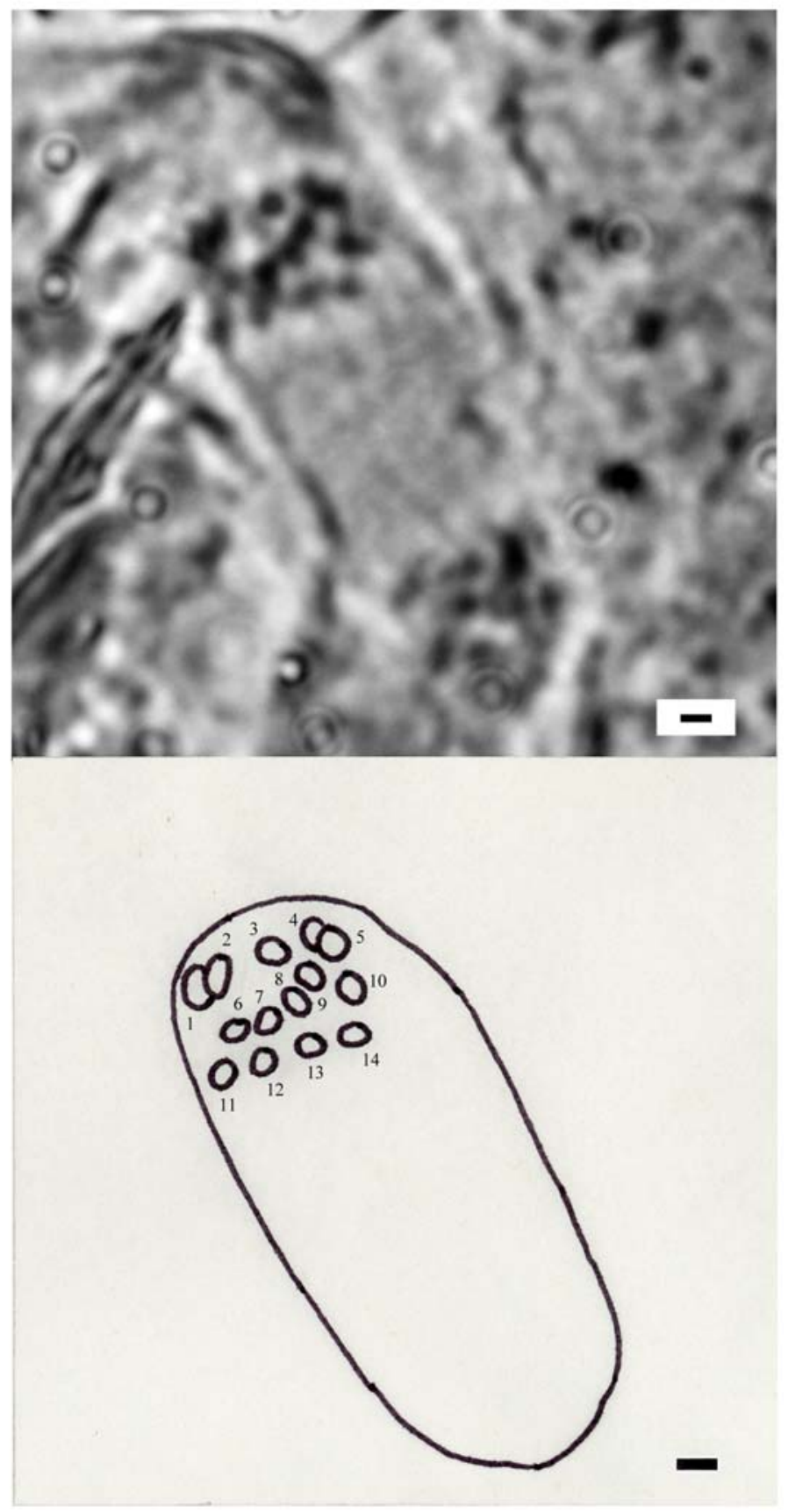

Figure 10. Meiotic chromosomes from a population in Pike County, Indiana (Sewell 421). Scale bar $1 \mu \mathrm{m}$. 


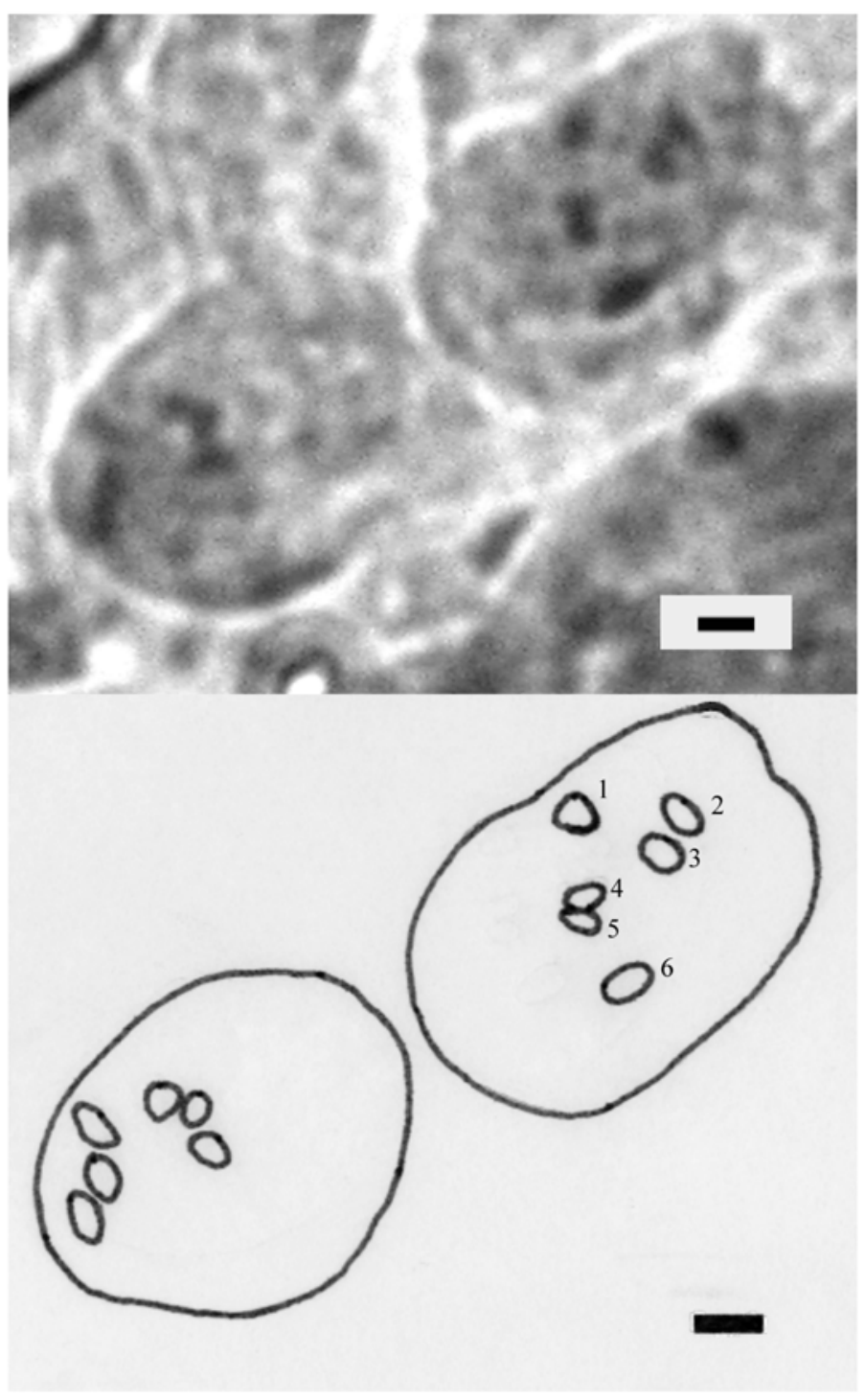

Figure 11. Meiotic chromosomes from a population in Wayne County, Missouri (Sewell 413). Scale bar $1 \mu \mathrm{m}$. 

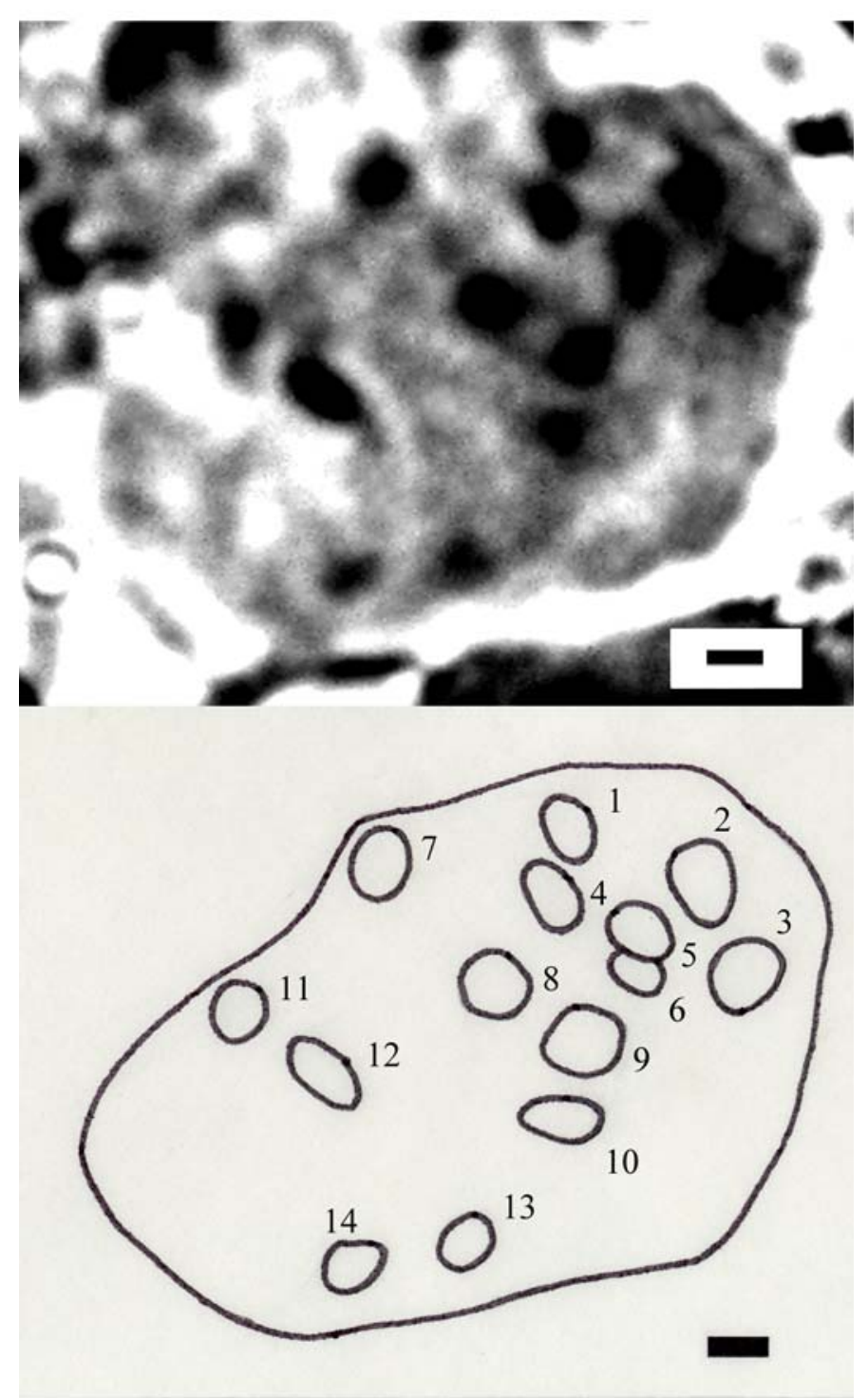

Figure 12. Meiotic chromosomes from a population in Lawrence County, Ohio (Sewell 370). Scale bar $1 \mu \mathrm{m}$. 


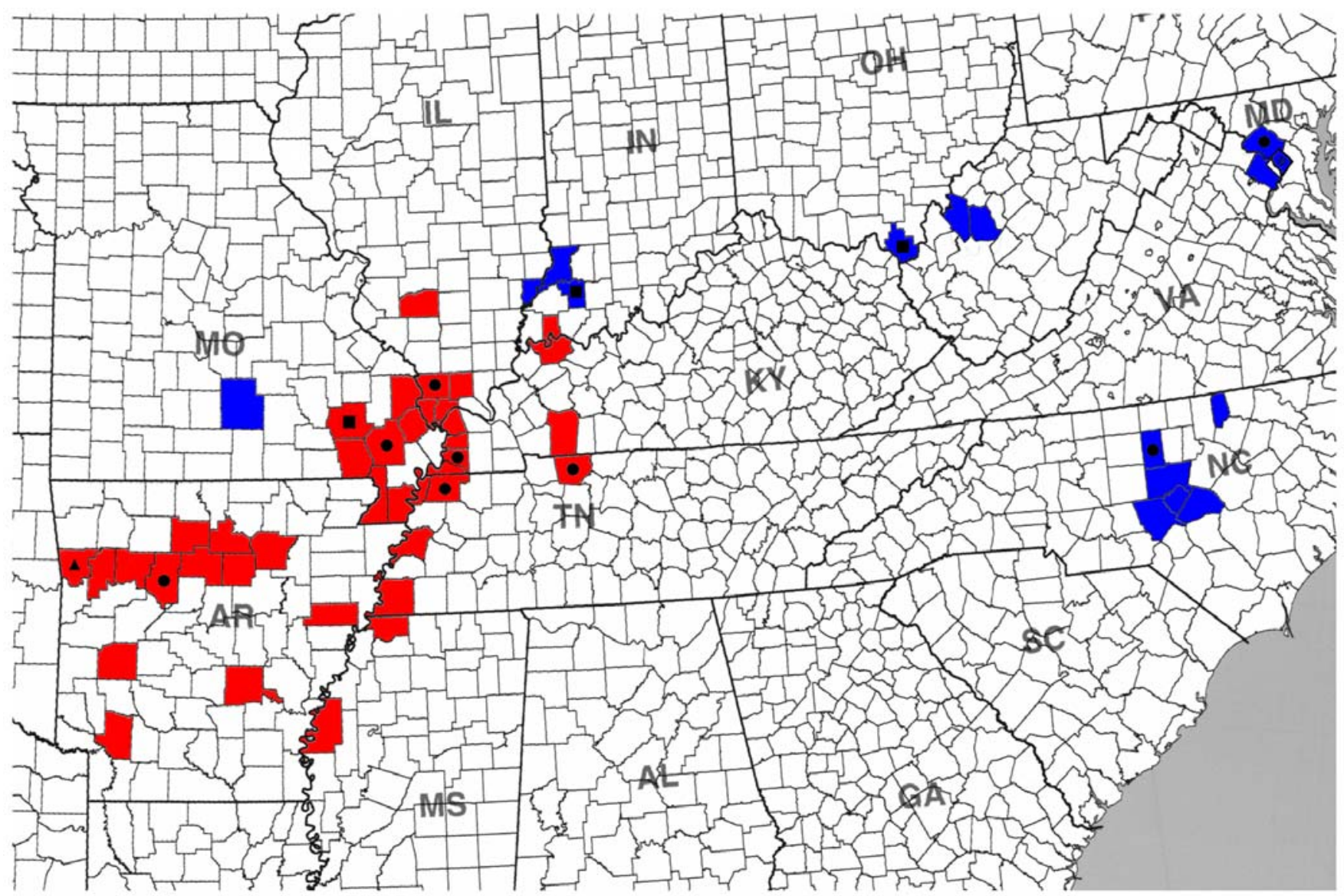

Phacelia covillei Wats. - populations with a $n=14$ morphology

$\square$ Phacelia ranunculacea (Nutt.) Constance - populations with a $n=6$ morphology

- Chuang \& Constance (1977) chromosome voucher

- Sewell (2003) chromosome voucher

* Constance (1949) chromosome voucher

$\Delta$ Smith \& Sherif (herbarium- UARK) chromosome voucher

Figure 13. Distribution of $P$. ranunculacea and $P$. covillei with chromosome vouchers indicated by county. 
Appendix A. Histograms of characters.
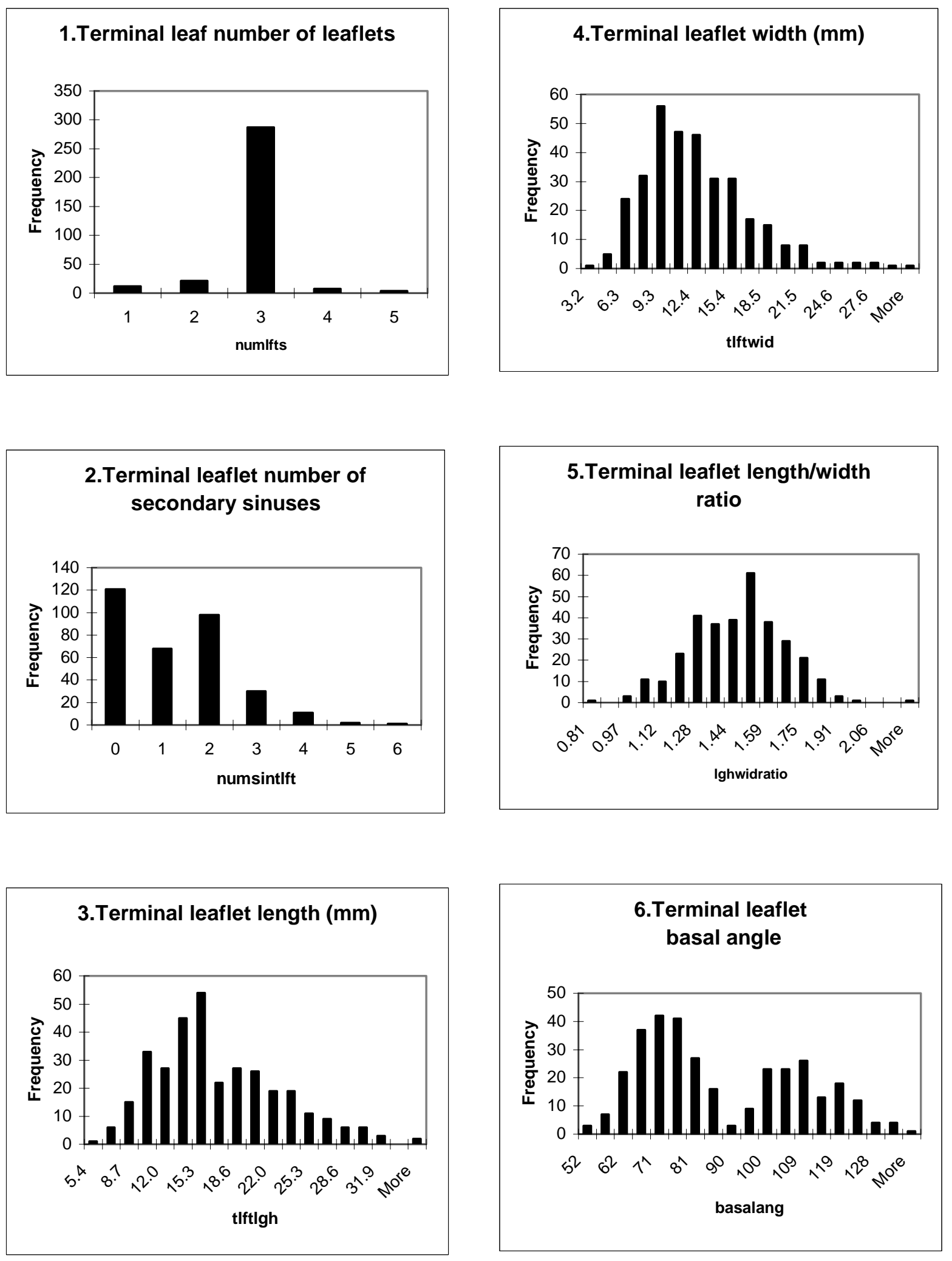

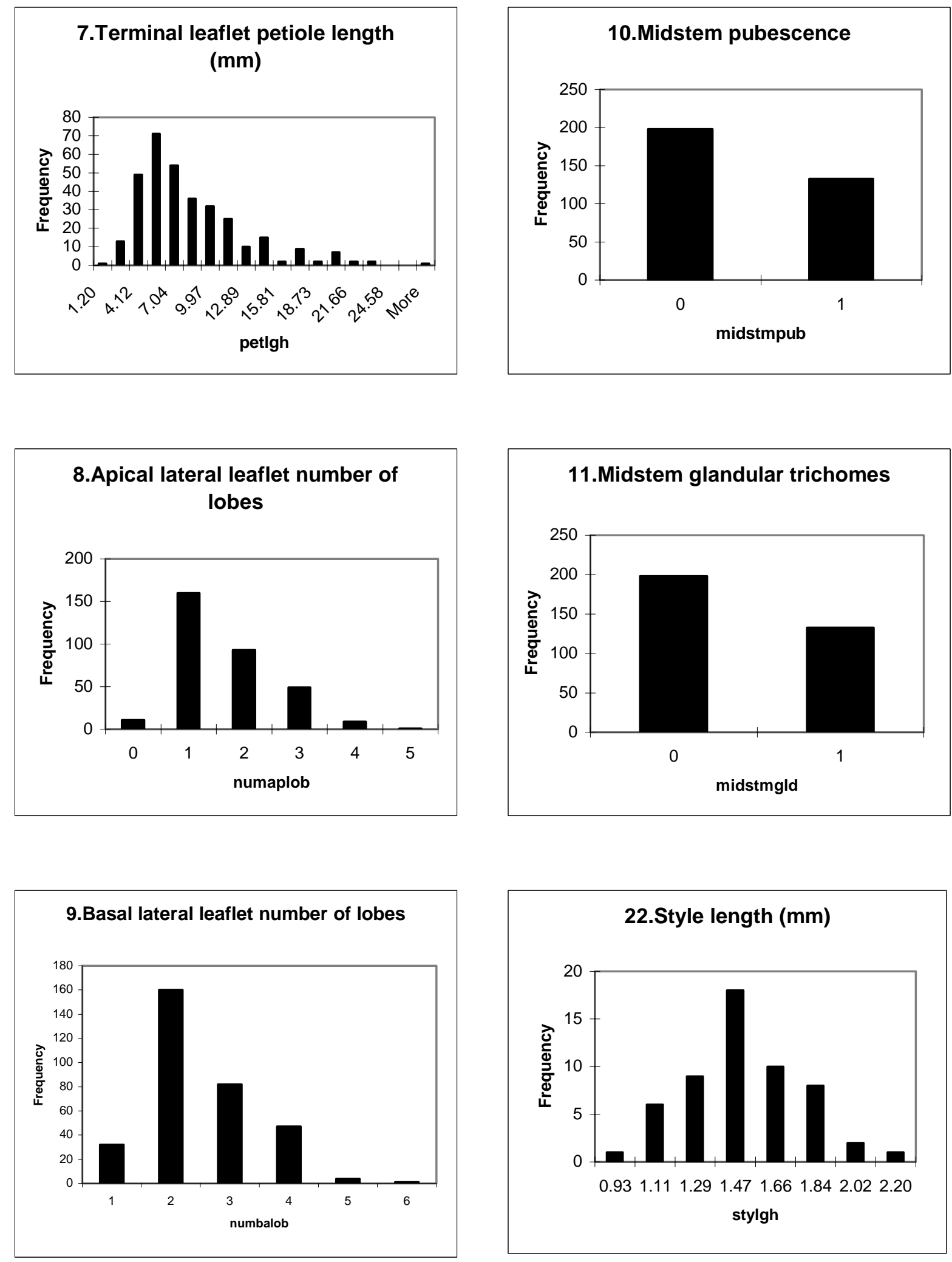

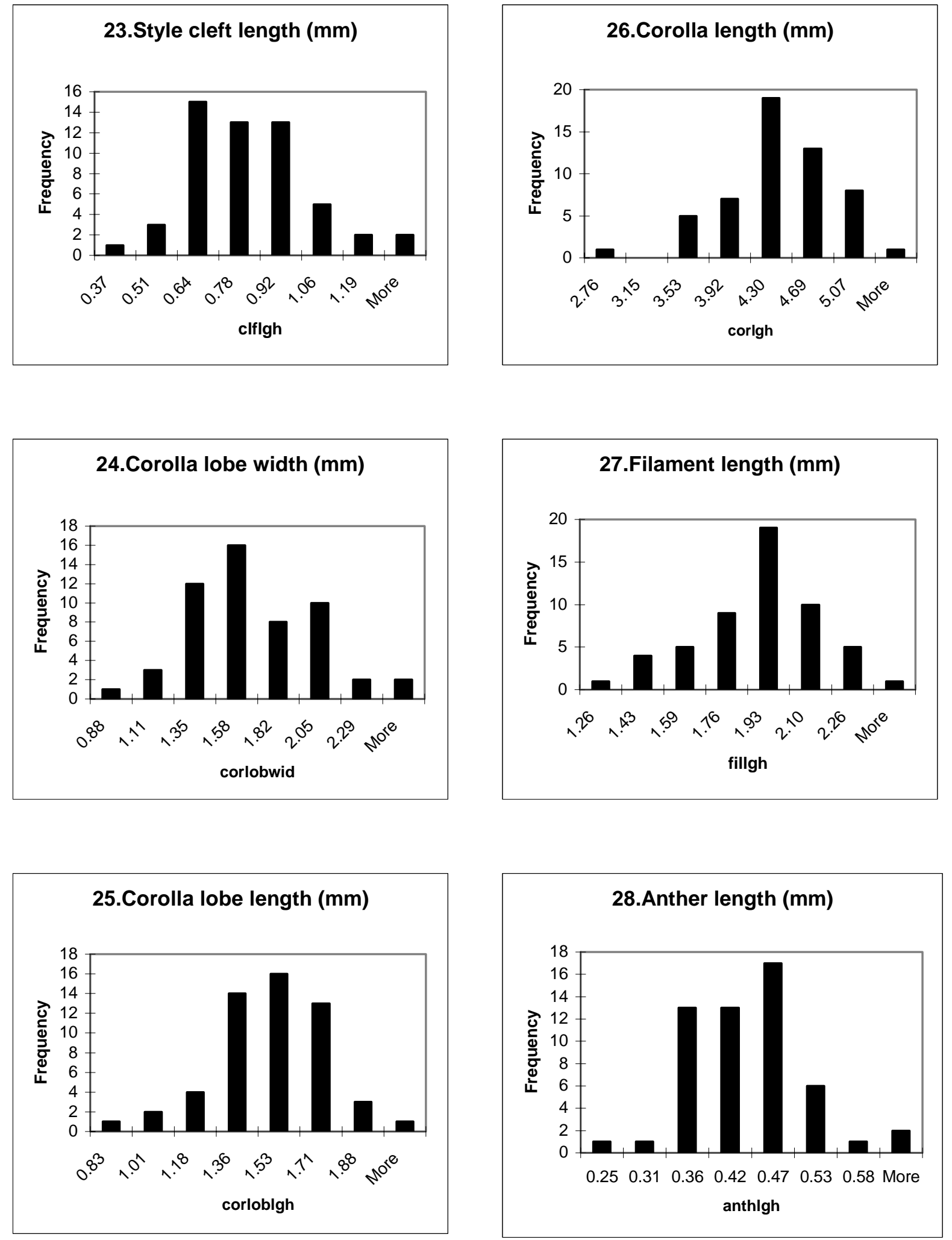

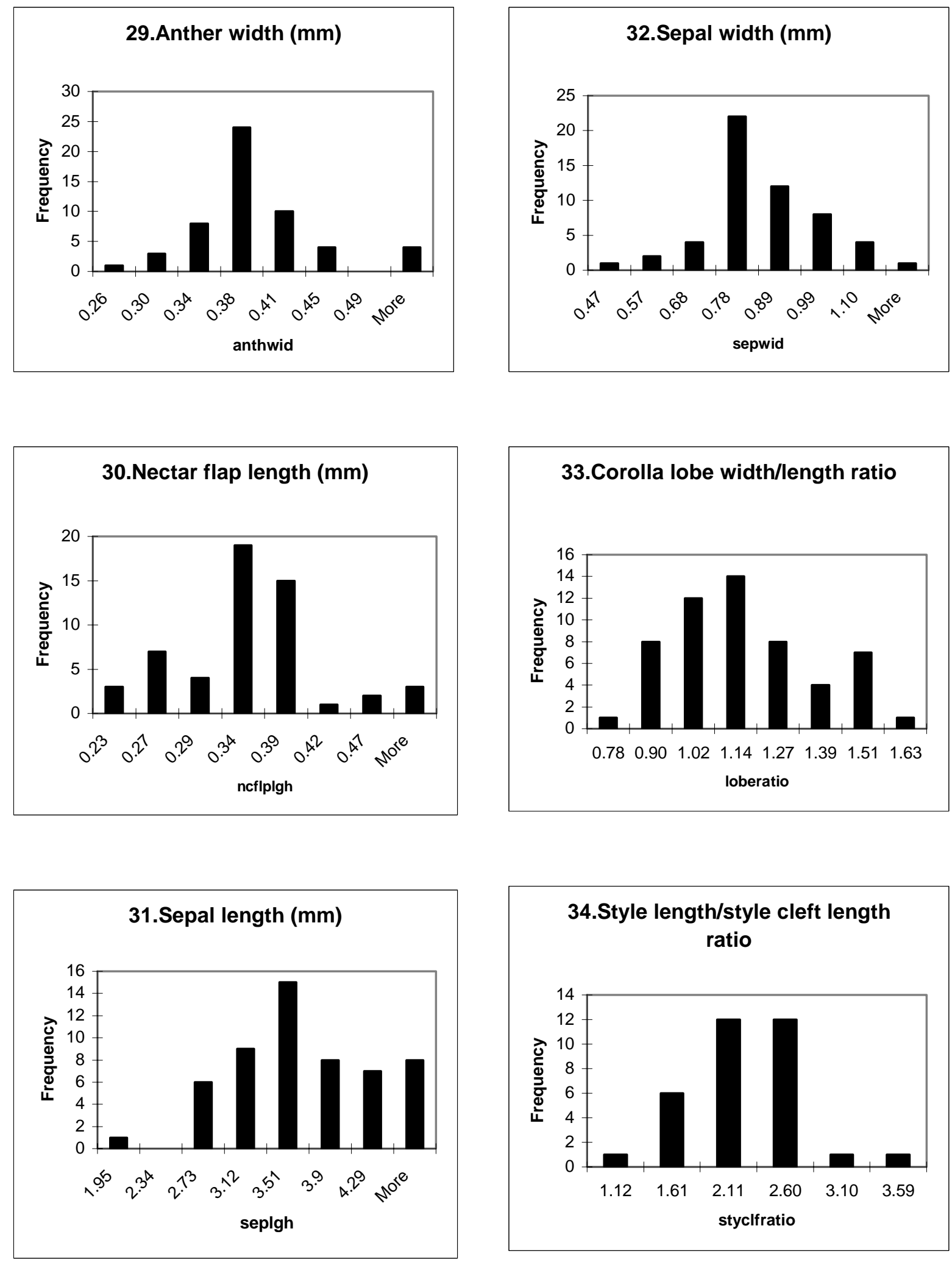
Appendix B. Specimens examined (collector numbers and OTU codes w/ chromosome vouchers in bold, \# = Type population, \% = different collections on the same sheet).

Phacelia covillei Wats. $(n=14)$

\begin{tabular}{|c|c|c|c|c|c|c|}
\hline State & County & Collector & Collector no. & OTU codes & Date & Herbaria \\
\hline North Carolina & Chatham & Ahles, H.E. & 53249 & NC $0101-17$ & April 25, 1960 & WVU, TENN, IND, ILL, BRIT(2), NCU, NY(2), KU, GH, US, UC/JEP \\
\hline North Carolina & Chatham & Radford, A.E. & 42786 & NC 0201 & April 24, 1960 & NCU \\
\hline North Carolina & Chatham & Sewell, M. & 330 & NC 1301 & April 14, 2001 & MU \\
\hline North Carolina & Chatham & Leonard, S.W. & 8360 & NC 1401 & April 22, 1984 & BRIT \\
\hline North Carolina & Chatham & Basinger & 3972 & NC 1501 & June 7, 1991 & ILL \\
\hline North Carolina & Harnett & Radford, A.E. & 7850 & NC 03 01-05 & April 10, 1954 & VPI, BRIT, NCU(2), GH \\
\hline North Carolina & Lee & Sewell, M. & 335 & NC 0401 & April 14, 2001 & $\mathrm{MU}$ \\
\hline North Carolina & Lee & Radford, A.E. & 5590 & NC 05 01-06 & April 27, 1951 & VPI, US, NCU, NY, GH, UC/JEP \\
\hline North Carolina & Lee & Radford, A.E. & 5577 & NC 0601 & April 27, 1951 & $\mathrm{NCU}$ \\
\hline North Carolina & Alamance & Chuang, T.I. & 6851 & NC 0702 & April 5, 1971 & UC/JEP \\
\hline North Carolina & Alamance & Radford, A.E. \& W. Hight & 5570 & NC 08 01-05 & April 23, 1951 & NCU, NY, GH, UC/JEP, US \\
\hline North Carolina & Alamance & Bradley, $\mathrm{T}$. & 248 & NC 0901 & April 17, 1963 & GMU \\
\hline North Carolina & Alamance & Logue, J.F. \& Spongberg, S. & 964 & NC 10 01,02,04 & April 11, 1967 & $\mathrm{NCU}(2), \mathrm{WKU}$ \\
\hline North Carolina & Moore & Sewell, M. & 337 & NC 1103 & April 14, 2001 & MU \\
\hline North Carolina & Moore & Legrand, H.E. & s.n. & NC 1104 & April 10, 1988 & $\mathrm{NCU}$ \\
\hline North Carolina & Vance & Legrand, H.E. & s.n. & NC 1202 & April 12, 1985 & $\mathrm{NCU}$ \\
\hline North Carolina & Vance & Mansberg, L. & 442 & NC 1204 & April 12, 1985 & NCU \\
\hline North Carolina & Vance & Legrand, H.E. & s.n. & NC 1205 & April 4, 1985 & $\mathrm{NCU}$ \\
\hline Washington, D.C. & & Constance, L. & 3018 & DC 01 02\&05-09 & May 2, 1943 & F, WVU, US, TENN, BRIT, MO, UC/JEP, PH, NY \\
\hline Maryland & Montgomery & Sewell, M. & 343 & MD 01 01\&02 & April 21, 2001 & MU \\
\hline Maryland & Montgomery & Sewell, M. & 345 & MD 0201 & April 21, 2001 & $\mathrm{MU}$ \\
\hline Maryland & Montgomery & Constance, L. & 3021 & MD 03 04-09\&11 & May 14, 1944 & F, WVU, US, ILL, BRIT, TENN, MO, NY, UC/JEP, PH \\
\hline Maryland & Montgomery & Hermann \& Martin & 56 & MD 04 01-10 & May 10, 1939 & F(2), VPI, WVU, US, TENN, NY, KU, PH(2) \\
\hline Maryland & Montgomery & Kearney, T.H. & s.n. & MD 0504 & April 23, 1897 & $\mathrm{NY}, \mathrm{NCU}$ \\
\hline Maryland & Montgomery & Kearney, T.H. & s.n. & MD 0601 & April 23, 1897 & NY \\
\hline Maryland & Montgomery & Kearney, T.H. & s.n. & MD 0701 & April 23, 1897 & NY \\
\hline Maryland & Montgomery & Kearney, T.H. & s.n. & MD 0801 & April 23, 1897 & MO \\
\hline Maryland & Montgomery & Kearney, T.H. & s.n. & MD 0901 & May 19, 1895 & NY \\
\hline Maryland & Montgomery & Kearney, T.H. & s.n. & MD 1001 & May 19, 1895 & $\mathrm{NCU}$ \\
\hline Maryland & Montgomery & Chase, A. & 2172 & MD 11 01\&03-05 & May 13,1904 & $F, \operatorname{ILL}(4)$ \\
\hline Maryland & Montgomery & Blake, S.F. & s.n. & MD 12 02-04 & April 27/May 5, 1935 & VPI, NCU, GH \\
\hline Maryland & Montgomery & Blake, S.F. & 8126 & MD 1301 & May 4, 1920 & $\mathrm{GH}$ \\
\hline Maryland & Montgomery & Blake, S.F. & 9360 & MD 1401 & May 2, 1926 & UC/JEP \\
\hline Maryland & Montgomery & Pollard, C.L. & 155 & MD 15 01-03 & May 8, 1895 & US, UC/JEP(2) \\
\hline Maryland & Montgomery & Pollard, C.L. & s.n. & MD 1601 & April 23, 1897 & $\mathrm{~F}$ \\
\hline Maryland & Montgomery & Hermann, F.J. & 10275 & MD $1701 \& 03$ & May 10, 1939 & $\mathrm{~F}, \mathrm{MO}$ \\
\hline
\end{tabular}




\begin{tabular}{|c|c|c|c|c|c|c|}
\hline State & County & Collector & Collector no. & OTU codes & Date & Herbaria \\
\hline Maryland & Montgomery & Sargent, F.H. & s.n. & MD 1802 & April 29, 1951 & BRIT \\
\hline Maryland & Montgomery & Churchill, J.A. & s.n. & MD 1902 & May 20, 1971 & BRIT \\
\hline Maryland & Montgomery & Bartram, E.B. & s.n. & MD 2001 & April 17, 1909 & $\mathrm{PH}$ \\
\hline Maryland & Montgomery & Painter, J.H. & 1336 & MD 2101 & May 25, 1905 & MO \\
\hline Maryland & Montgomery & Painter, J.H. & s.n. & MD 2201 & 17-May-03 & $\mathrm{MO}$ \\
\hline Maryland & Montgomery & Batchelder, C.F. & 2932 & MD 2301 & May 10, 1911 & $\mathrm{GH}$ \\
\hline Maryland & Montgomery & Batchelder, C.F. & 2933 & MD 2302 & May 10, 1911 & $\mathrm{GH}$ \\
\hline Maryland & Montgomery & House, H.D. & 841 & MD $2401 \& 04$ & May 25, 1905 & US, MO, NY \\
\hline Maryland & Montgomery & Hill, S.R. & 16707 & MD 25 01-05 & May 4, 1986 & ILL, MO, NCU, NY, GH \\
\hline Maryland & Montgomery & Maxon \& Standley & 337 & MD 2602 & May 20, 1916 & US \\
\hline Maryland & Montgomery & Leonard, E.C. & 1784 & MD 2702 & April 3, 1921 & US \\
\hline Maryland & Montgomery & Sargent, F.H. & s.n. & MD 2801 & May 7, 1950 & WVU \\
\hline Maryland & Montgomery & McVaugh, R. & 4920 & MD 2902 & May 28,1940 & UC/JEP \\
\hline Maryland & Montgomery & Wurdack, J.J. & 2632 & MD 3001 & May 2, 1970 & UC/JEP \\
\hline Maryland & Montgomery & Hunnewell, F.W. & 5902 & MD 3101 & April 19, 1919 & $\mathrm{GH}$ \\
\hline Maryland & Montgomery & Long, B. & s.n. & MD 3201 & April 17, 1908 & VPI \\
\hline Maryland & Montgomery & Killip, E.P. & 7457 & MD 3303 & April 3, 1921 & MO \\
\hline Maryland & Montgomery & Gandoger, M. & s.n. & MD 3401 & 1902 & MO \\
\hline Maryland & Montgomery & Britton, N.L. & s.n. & MD 3501 & May 21, 1902 & NY \\
\hline Maryland & Montgomery & Rose, J.N. & 1146 & MD 3601 & April 23, 1897 & NY \\
\hline Maryland & Montgomery & Pennell, F.W. & 14991 & MD 37 01-02 & May 4, 1930 & $\mathrm{NY}, \mathrm{PH}$ \\
\hline Maryland & Montgomery & Greene, E.S. & s.n. & MD 3801 & May 2, 1898 & NY \\
\hline Maryland & Montgomery & Terrell, E.E. & 4082 & MD 3901 & April 27, 1968 & US \\
\hline Maryland & Montgomery & Steele, E.S. & s.n. & MD 4001 & April 30, 1897 & $\mathrm{GH}$ \\
\hline Maryland & Montgomery & Steele, E.S. & s.n. & MD 4101 & April 30, 1897 & WVU \\
\hline Maryland & Montgomery & Steele, E.S. & s.n. & MD 4201 & April 30, 1897 & MU \\
\hline Maryland & Montgomery & Steele, E.S. & 8319 & MD 4301 & April 30, 1897 & $\mathrm{GH}$ \\
\hline Maryland & Montgomery & Steele, E.S. & s.n. & MD 4401 & April 24, 1916 & US \\
\hline Maryland & Montgomery & Waite, M.B. & s.n. & & May 19, 1895 & $\mathrm{GH}$ \\
\hline Maryland & Montgomery & Williamson, C.S. & s.n. & MD 4601 & April 21, 1908 & $\mathrm{PH}$ \\
\hline Maryland & Montgomery & Williamson, C.S. & s.n. & & May 30, 1909 & $\mathrm{PH}$ \\
\hline Maryland & Montgomery & Williamson, C.S. & s.n. & & May 29, 1909 & $\mathrm{PH}$ \\
\hline Maryland & Montgomery & Williamson, C.S. & $\%$ s.n. & \%MD 4802 & May 29, 1909 & PH \\
\hline Maryland & Montgomery & Williamson, C.S. & $\%$ s.n. & \%MD 4901 & May 1897 & $\mathrm{PH}$ \\
\hline Maryland & Montgomery & Williamson, C.S. & \%s.n. & \%MD 5001 & April 17, 1908 & $\mathrm{PH}$ \\
\hline Maryland & Montgomery & Williamson, C.S. & s.n. & MD 5002 & April 17, 1908 & $\mathrm{PH}$ \\
\hline Maryland & Montgomery & Williamson, C.S. & s.n. & MD 5101 & May & $\mathrm{PH}$ \\
\hline Maryland & Montgomery & Coville, F.V. & \#s.n. & \#MD 5201 & May 5/12, 1889 & $\mathrm{KU}$ \\
\hline Maryland & Montgomery & Coville, F.V. & \#s.n. & \#MD 5202 & May 12, 1889 & US \\
\hline Maryland & Montgomery & Coville, F.V. & \#s.n. & \#MD 52 03,05,06 & May 5/12, 1889 & $\mathrm{GH}$ \\
\hline
\end{tabular}




\begin{tabular}{|c|c|c|c|c|c|c|}
\hline State & County & Collector & Collector no. & OTU codes & Date & Herbaria \\
\hline Maryland & Montgomery & Coville, F.V. & \#s.n. & & May 5, 1889 & NY \\
\hline Virginia & Fairfax & Sewell, M. & 347 & VA 0101 & April 21, 2001 & MU \\
\hline Virginia & Fairfax & Fleming, G.P. & 6377 & VA 02 01-03 & May 7, 1992 & VPI, GMU(2) \\
\hline Virginia & Fairfax & Fleming, G.P. & 6382 & VA 0301 & May 7, 1992 & GMU \\
\hline Virginia & Fairfax & Dowell, P.L. & 1341 & VA 0401 & May 4, 1902 & $\mathrm{GH}$ \\
\hline Virginia & Fairfax & Palmer, W. & s.n. & & May 5, 1901 & VPI \\
\hline Virginia & Fairfax & Maxon, W.R. & 513 & VA 0601 & May 3, 1902 & US \\
\hline Virginia & Arlington & Allard, H.A. & 21311 & VA $0701-03$ & April 23, 1953 & WVU, US, PH \\
\hline Virginia & Arlington & Allard, H.A. & 4513 & VA 07 04-09 & April 26, 1938 & VPI, MO, NY, GH, F, UC/JEP \\
\hline Virginia & Arlington & Allard, H.A. & 281 & VA 07 10-15 & May 2, 1935 & F, VPI, US, MO, NY, GH \\
\hline Virginia & Arlington & Allard, H.A. & 2534 & VA $0801-04$ & April 22, 1937 & US, NY, VPI, GH \\
\hline Ohio & Lawrence & Sewell, M. & 364 & OH 0101 & May 5, 2001 & MU \\
\hline Ohio & Lawrence & Sewell, M. & 370 & OH 02 01-02 & May 5, 2001 & MU \\
\hline Ohio & Lawrence & McCormac, J. & 5778 & $\mathrm{OH} 0301$ & May 16, 1997 & $\mathrm{MU}$ \\
\hline Ohio & Lawrence & Sewell, M. & 373 & $\mathrm{OH} 0401$ & May 5, 2001 & $\mathrm{MU}$ \\
\hline Ohio & Lawrence & McCormac, J. & 6493 & $\mathrm{OH} 0501$ & April 28, 1998 & MU \\
\hline West Virginia & Roane & Bush, E. & s.n. & WV 0101 & May 5, 1991 & WVU \\
\hline West Virginia & Roane & Bush, E. & s.n. & WV 0201 & May 5, 1990 & WVU \\
\hline West Virginia & Roane & Bush, E. & s.n. & WV 0301 & May 5, 1990 & UC/JEP \\
\hline West Virginia & Roane & Rossbach, G.B. & 12106 & WV 0401 & May 9, 1996 & WVU \\
\hline West Virginia & Roane & Bush, E. & s.n. & WV 0501 & May 5, 1988 & WVU \\
\hline West Virginia & Jackson & Richardson, $\mathrm{R}$. & s.n. & WV 0601 & May 5, 1969 & WVU \\
\hline West Virginia & Jackson & Richardson, R. & s.n. & WV 0701 & May 15, 1969 & WVU \\
\hline West Virginia & Jackson & Sewell, M. & 377 & WV 0801 & May 6, 2001 & MU \\
\hline West Virginia & Jackson & Richardson, R. & s.n. & WV 0901 & April 28, 1974 & WVU \\
\hline Indiana & Knox & Deam, C.C. & 44032 & IN 01 01-05 & April 19, 1927 & IND, GH, UARK, US \\
\hline Indiana & Knox & Deam, C.C. & 42896 & IN 02 01-04 & May 23, 1926 & IND(2), NY, PH \\
\hline Indiana & Knox & Deam, C.C. & s.n. & IN 0301 & May 26, 1926 & MO \\
\hline Indiana & Knox & Schneck, J. & s.n. & IN 0401 & May 16, 1896 & IND \\
\hline Indiana & Knox & Schneck, J. & s.n. & IN 0501 & April 20, 1903 & IND \\
\hline Indiana & Knox & Trelease, W. \& J. Schneck & s.n. & IN 0601 & May 8, 1888 & MO \\
\hline Indiana & Knox & Blatchley, W.S. & s.n. & IN 0701 & April 23, 1903 & IND \\
\hline Indiana & Pike & Sewell, M. & 421 & IN 1001 & April 16, 2003 & MU \\
\hline Indiana & Pike & Sewell, M. & 422 & IN 1101 & April 16, 2003 & MU \\
\hline Illinois & Wabash & Schneck, H. & s.n. & IL 1301 & May 19, 1896 & NY \\
\hline Missouri & Texas & Sewell, M. & 396 & & March 30, 2002 & $\mathrm{MU}$ \\
\hline Missouri & Texas & Steyermark, J.A. & 73166 & MO 01 02-06 & April 28, 1952 & $\mathrm{~F}, \mathrm{MO}, \mathrm{NY}, \mathrm{US}, \mathrm{UC} / \mathrm{JEP}$ \\
\hline
\end{tabular}


Phacelia ranunculacea (Nutt.) Constance $(n=6)$

\begin{tabular}{|c|c|c|c|c|c|c|}
\hline State & County & Collector & Collector no. & OTU codes & Date & Herbaria \\
\hline Indiana & Vanderburgh & Sewell, M. & 404 & IN $0801 \& 02$ & April 12, 2002 & $\mathrm{MU}$ \\
\hline Indiana & Vanderburgh & Schaust, J. & s.n. & & May 1983 & IND \\
\hline Illinois & Alexander & Sewell, M. & 411 & IL $0101 \& 02$ & April 14, 2002 & MU \\
\hline Illinois & Alexander & Basinger & 5014 & IL 0201 & May 9, 1993 & ILL \\
\hline Illinois & Alexander & Ozment \& Windler & 5 & IL 0301 & April 10, 1964 & NCU \\
\hline Illinois & Alexander & Phillippe & 23489 & IL 0401 & April 12, 1994 & ILL \\
\hline Illinois & Johnson & Winterringer, G.S. & 9003 & IL 0501 & May 14, 1952 & ILL \\
\hline Illinois & Pulaski & Sewell, M. & 406 & IL 0601 & April 13, 2002 & MU \\
\hline Illinois & Pulaski & Hill, S.R. & 27804 & IL 07 01-03 & May 7, 1996 & ILL, NY, MU \\
\hline Illinois & Union & Sewell, M. & 410 & IL 0801 & April 13, 2002 & $\mathrm{MU}$ \\
\hline Illinois & Union & Pepoon, H.S. & s.n. & IL 0901 & May, 1932 & ILL \\
\hline Illinois & Union & Sewell, M. & 409 & IL 1001 & April 13, 2002 & MU \\
\hline Illinois & Union & Phillippe & 18569 & IL 1002 & April 10, 1991 & ILL \\
\hline Illinois & Union & Chuang, T.I. & 7240 & IL 1101 & April 28, 1973 & UC/JEP \\
\hline Illinois & Union & Chuang, T.I. & 7240 & IL 1102 & April 28, 1973 & UC/JEP \\
\hline Illinois & Union & Chuang, T.I. & 6608 & IL 12 01\&02 & 25-Apr-69 & UC/JEP \\
\hline Illinois & Union & Chuang, T.I. & 6608 & & May 1969 & UC/JEP \\
\hline Illinois & Washington & French, G.H. & 11 & IL 1401 & 1873 & us \\
\hline Missouri & Stoddard & Sewell, M. & 399 & & March 31, 2002 & MU \\
\hline Missouri & Stoddard & Chuang, T.I. & 6758 & MO 0205 & March 27, 1970 & UC/JEP \\
\hline Missouri & Stoddard & Steyermark, J.A. & 80911 & MO $0203 \& 04$ & April 7, 1956 & ILL, MO \\
\hline Missouri & Stoddard & Steyermark, J.A. & 5074 & MO 03 01-03 & April 25, 1938 & $\mathrm{~F}, \mathrm{MO}, \mathrm{UC} / \mathrm{JEP}$ \\
\hline Missouri & Wayne & Bush, B.F. & 1458 & MO $0401 \& 02$ & April 29, 1902 & NY, MO \\
\hline Missouri & Wayne & Sewell, M. & 413 & MO 05 01\&02 & April 14, 2002 & MU \\
\hline Missouri & Wayne & Hudson, S. & s.n. & MO 0503 & May 26, 1992 & MO \\
\hline Missouri & Butler & Sewell, M. & 397 & & March 31, 2002 & MU \\
\hline Missouri & Butler & Summers, B. & 8531 & MO 0701 & May 3, 1998 & MO \\
\hline Missouri & Butler & Steyermark, J.A. & 80823 & MO $0801 \& 02$ & April 5, 1956 & $\mathrm{MO}, \mathrm{GH}$ \\
\hline Missouri & Butler & Hudson, S. & 855 & & February 13, 1996 & MO \\
\hline Missouri & Butler & Hudson, S. & 665 & MO 0902 & April 9, 1995 & MO \\
\hline Missouri & Pemiscot & Steyermark, J.A. & 80876 & MO $1001 \& 02$ & April 6, 1956 & $\mathrm{GH}, \mathrm{MO}$ \\
\hline Missouri & Pemiscot & Steyermark, J.A. & 5121 & MO 11 01\&02 & April 26, 1938 & $\mathrm{~F}, \mathrm{MO}$ \\
\hline Missouri & Scott & Steyermark, J.A. & 4995 & MO 12 01\&03 & April 23, 1938 & $\mathrm{~F}, \mathrm{MO}$ \\
\hline Missouri & Dunklin & Trelease, W. & 496 & & April 24, 1897 & MO \\
\hline Missouri & Dunklin & Kellogg, J.H. & 25921 & MO 14 01\&03 & May 23, 1932 & $\mathrm{MO}(2)$ \\
\hline Missouri & Dunklin & Palmer, E.J. & 39064 & MO 1501 & April 24, 1931 & $\mathrm{GH}$ \\
\hline Missouri & Dunklin & Bush, B.F. & 1024 & & May 23, 1892 & MO \\
\hline Missouri & $?$ & James(Dr.) & s.n. & & s.d. & NY \\
\hline
\end{tabular}




\begin{tabular}{|c|c|c|c|c|c|c|}
\hline State & County & Collector & Collector no. & OTU codes & Date & Herbaria \\
\hline Tennessee & Obion & Sewell, M. & 349 & TN 0101 & April 28, 2001 & $\mathrm{MU}$ \\
\hline Tennessee & Obion & Guthrie, M. & 723 & TN 0301 & April 10, 1986 & BRIT \\
\hline Tennessee & Obion & Guthrie, M. & 726 & TN 04 01\&02 & April 10, 1986 & BRIT(2) \\
\hline Tennessee & Obion & Guthrie, M. & 750 & TN 0502 & April 13, 1986 & NY, BRIT \\
\hline Tennessee & Obion & Guthrie, M. & 775 & TN 06 01\&02 & April 16, 1986 & TENN, BRIT \\
\hline Tennessee & Obion & Guthrie, M. & 811 & TN 07 01-03 & April 26, 1986 & BRIT(2), TENN \\
\hline Tennessee & Obion & Pyne, M. G. & 1672 & TN 08 01\&02 & April 9, 1987 & TENN, BRIT \\
\hline Tennessee & Obion & Sharp, A.J., et. al. & 12286 & TN 09 02\&03 & April 30, 1949 & TENN, BRIT, NCU \\
\hline Tennessee & Obion & Chuang, T.I. & 6855 & TN 10 02\&03 & April 8, 1971 & UC/JEP(2) \\
\hline Tennessee & Montgomery & Somers, P. & 1030 & TN 1101 & April 19, 1978 & BRIT \\
\hline Tennessee & Montgomery & Wofford, B.E. & 4 & TN 12 01\&02 & April 28, 1993 & TENN, NY \\
\hline Tennessee & Montgomery & Chuang, T.I. & 6854 & TN 13 01\&03 & April 7, 1971 & TENN, UC/JEP \\
\hline Tennessee & Montgomery & Clebsch, A. & s.n. & TN 1401 & April 23, 1949 & TENN \\
\hline Tennessee & Montgomery & Clebsch, A. & 110 & TN 1502 & April 10, 1948 & TENN, NCU \\
\hline Tennessee & Montgomery & Fox, H. & s.n. & TN 1601 & April 16, 1917 & $\mathrm{PH}$ \\
\hline Tennessee & Montgomery & Chester, W. & 1996 & TN 17 01\&03 & April 16, 1968 & TENN, BRIT \\
\hline Tennessee & Montgomery & Brown, F. \& Clebsch, A. & s.n. & TN 1802 & April 7, 1957 & $\mathrm{NCU}$ \\
\hline Tennessee & Shelby & Pyne, M. & 12 & TN 19 01\&02 & April 4, 1992 & TENN, BRIT \\
\hline Tennessee & Shelby & Bates, V.M. & 1753 & TN 2001 & May 17,1980 & TENN \\
\hline Tennessee & Shelby & Bates, V.M. & 2154 & & April 16, 1981 & TENN \\
\hline Tennessee & Shelby & Fendler, A. & s.n. & TN 2202 & March 29, 1896 & MO \\
\hline Tennessee & Shelby & Moore, C. & 7 & TN 2301 & April 1932 & MO \\
\hline Tennessee & Lake & Jones, R.L. & s.n. & TN 2401 & April 8, 1990 & EKU \\
\hline Tennessee & Lauderdale & Keiran, P. & 249 & TN 2501 & March 31, 1972 & TENN \\
\hline Kentucky & Christian & McKinney, L.E. & 6124 & KY 0101 & April 7, 1994 & TENN \\
\hline Kentucky & Christian & Athey, R. & 4017 & KY 0201 & May 19, 1978 & BRIT \\
\hline Kentucky & Christian & Athey, R. & 3941 & KY 0202 & April 23, 1978 & BRIT \\
\hline Kentucky & Henderson & Sewell, M. & 401 & KY 0301 & April 12, 2002 & $\mathrm{MU}$ \\
\hline Kentucky & Henderson & Wharton, M.E. & 9825 & KY $0401-03$ & May 4, 1956 & EKU(2), KU \\
\hline Kentucky & Henderson & Marx, P. & 691 & KY 0501 & April 22, 1973 & $\mathrm{NCU}$ \\
\hline Kentucky & Ballard & Athey, R. & 3279 & KY 06 01\&02 & April 23, 1976 & BRIT, WKU \\
\hline Kentucky & Fulton & Sewell, M. & 360 & KY 0701 & April 28, 2001 & $\mathrm{MU}$ \\
\hline Kentucky & Fulton & McKinney, L.E. & 4068 & KY 0801 & April 16, 1990 & BRIT \\
\hline Kentucky & Fulton & Athey, R. & 1307 & KY 09 01-03 & May 1, 1971 & NCU, NY, GH \\
\hline Kentucky & Carlisle & Sewell, M. & 362 & KY 1001 & April 28, 2001 & $\mathrm{MU}$ \\
\hline Kentucky & Carlisle & Wilson, L.M. & 287 & KY 1101 & May 3, 1975 & $\mathrm{NCU}$ \\
\hline Kentucky & Carlisle & Athey, R. & 1287 & KY 12 01-04 & April 10, 1971 & NCU, NY, GH, WKU \\
\hline Kentucky & Hickman & Beck, J. & 11 & KY 1301 & April 19, 1997 & EKU \\
\hline Kentucky & Hickman & Bryan, C. & 153 & KY 1402 & May 2, 1975 & $\mathrm{NCU}$ \\
\hline
\end{tabular}




\begin{tabular}{|c|c|c|c|c|c|c|}
\hline State & County & Collector & Collector no. & OTU codes & Date & Herbaria \\
\hline Kentucky & Hickman & Chuang, T.I. & 6856 & KY 1501 & April 8, 1971 & UC/JEP \\
\hline Arkansas & Pope & Mathis, G. & 27 & AR 0101 & April 16, 1970 & UC/JEP \\
\hline Arkansas & Pope & Tucker, G. & 8478 & AR 0202 & April 26, 1971 & UC/JEP \\
\hline Arkansas & Pope & Luers, M. & 59 & AR 0301 & April 1, 1976 & UARK \\
\hline Arkansas & Pope & Thompson, M. & 43 & AR 0401 & April 5, 1977 & UARK \\
\hline Arkansas & Pope & Bourne, T.F. & 52 & AR 0501 & April 5, 1980 & BRIT \\
\hline Arkansas & St. Francis & McDaniel, S. & 722 & AR 0601 & April 14, 1957 & UARK \\
\hline Arkansas & St. Francis & McDaniel, S. & 10465 & AR $0701 \& 02$ & April 14, 1968 & BRIT(2) \\
\hline Arkansas & Cleburne & Demaree, D. & 64458 & AR 0801 & April 8, 1972 & BRIT \\
\hline Arkansas & Crawford & Smith, E.B. \& A.S. Sherif & 14 & AR $0902 \& 03$ & March 27, 1980 & UARK(2) \\
\hline Arkansas & Crawford & Hayes, C. & 1238 & AR 1001 & April 12, 1975 & UARK \\
\hline Arkansas & Franklin & Barber, G. & 604 & AR 1101 & April 23, 1978 & UARK \\
\hline Arkansas & Hempstead & Sundell, E. & 12087 & AR 1201 & April 23, 1997 & UARK \\
\hline Arkansas & Independence & Board, V.V. & s.n. & AR 1301 & April 29, 1980 & UARK \\
\hline Arkansas & Jefferson & Locke, M. & 2128 & AR 1401 & April 8, 1977 & UARK \\
\hline Arkansas & Jefferson & Locke, M. & 1300 & AR 1501 & March 17, 1974 & UARK \\
\hline Arkansas & Johnson & Moore, D.M. & 330042 & AR 1601 & April 13, 1933 & UARK \\
\hline Arkansas & Searcy & Beer, M.A. & 54 & AR 1701 & April 11, 1992 & UARK \\
\hline Arkansas & Stone & Beer, M.A. & 55 & AR 1801 & April 26, 1993 & UARK \\
\hline Arkansas & Van Buren & Beer, M.A. & 69 & AR 1901 & March 28, 1991 & UARK \\
\hline Arkansas & Montgomery & Kral, R. & 77551 & AR 2001 & May 12, 1990 & BRIT \\
\hline Arkansas & Montgomery & Demaree, D. & 55109 & AR 2101 & April 5, 1967 & NKU \\
\hline Arkansas & $?$ & Nuttall & s.n. & & s.d. & UC/JEP(photo of ISOTYPE @ K) \\
\hline Arkansas & $?$ & Nuttall & s.n. & & s.d. & UC/JEP(photo of HOLOTYPE @ BM) \\
\hline Arkansas & $?$ & Nutthall & s.n. & & s.d. & GH(photo of ISOTYPE @ K) \\
\hline Mississippi & Bolivar & Bryson, C.T. & 10551 & MS 0101 & April 3, 1991 & BRIT \\
\hline Mississippi & DeSoto & McDaniel, S. & 10477 & MS 0201 & April 15, 1968 & BRIT \\
\hline
\end{tabular}

